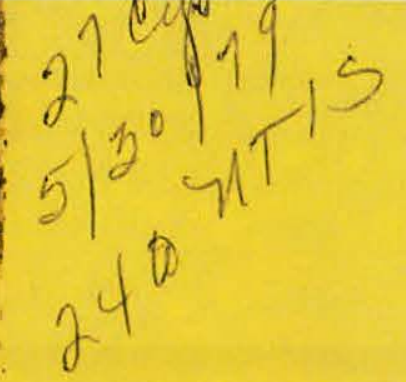

\title{
Ocean Thermal Energy Conversion Program
}

\section{Argonne National Laboratory}

\section{Sponsored by}

U. S. Department of Energy under Contract W-31-109-Eng-38 


\section{DISCLAIMER}

This report was prepared as an account of work sponsored by an agency of the United States Government. Neither the United States Government nor any agency Thereof, nor any of their employees, makes any warranty, express or implied, or assumes any legal liability or responsibility for the accuracy, completeness, or usefulness of any information, apparatus, product, or process disclosed, or represents that its use would not infringe privately owned rights. Reference herein to any specific commercial product, process, or service by trade name, trademark, manufacturer, or otherwise does not necessarily constitute or imply its endorsement, recommendation, or favoring by the United States Government or any agency thereof. The views and opinions of authors expressed herein do not necessarily state or reflect those of the United States Government or any agency thereof. 


\section{DISCLAIMER}

Portions of this document may be illegible in electronic image products. Images are produced from the best available original document. 


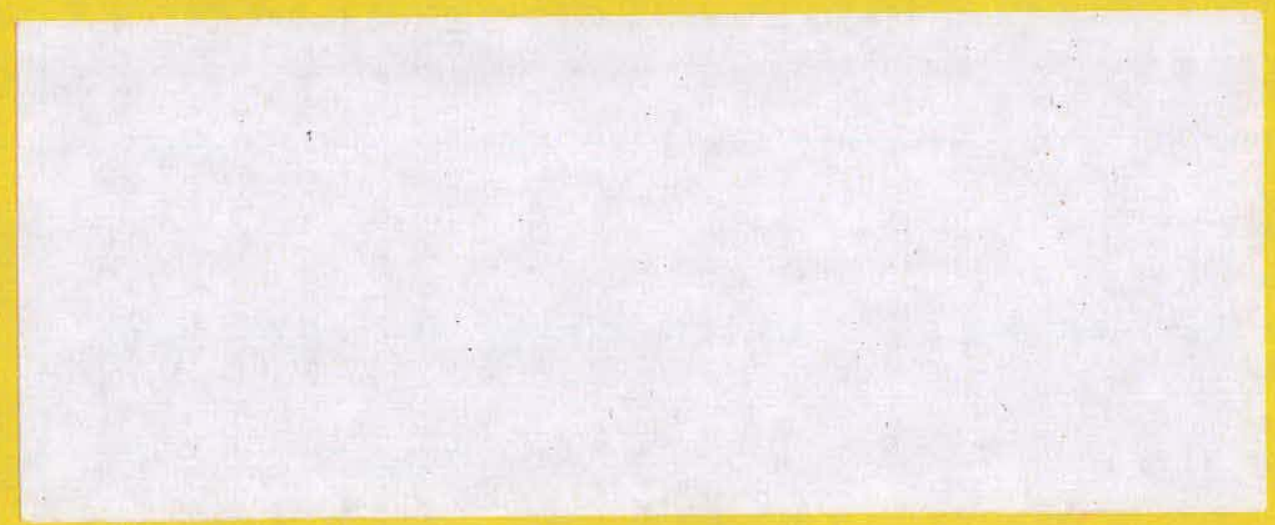

The facilities of Argonne National Laboratory are owned by the United States Government. Under the terms of a contract (W-31-109-Eng-38) between the U.S. Department of Energy, Argonne Universities Association and The University of Chicago, the University employs the staff and operates the Laboratory in accordance with policies and programs formulated, approved and reviewed by the Association.

\section{MEMBERS OF ARGONNE UNIVERSITIES ASSOCIATION}

The University of Arizona

Carnegie-Mellon University

Case Western Reserve University

The University of Chicago

University of Cincinnati

IIlinois Institute of Technology

University of Illinois

Indiana University

lowa State University

The University of lowa
Kansas State University

The University of Kansas

Loyola University

Marquette University

Michigan State University

The University of Michigan

University of Minnesota

University of Missouri

Northwestern University

University of Notre Dame
The Ohio State University

Ohio University

The Pennsylvania State University

Purdue University

Saint Louis University

Southern Illinois University

The University of Texas at Austin

Washington University

Wayne State University

The University of Wisconsin

\section{NOTICE}

This report was prepared as an account of work sponsored by the United States Government. Neither the United States nor the United States Department of Energy, nor any of their employees, nor any of their contractors, subcontractors, or their employees, makes any warranty, express or implied, or assumes any legal liability or responsibility for the accuracy, completeness or usefulness of any information, apparatus, product or process disclosed, or represents that its use would not infringe privately-owned rights. Mention of commercial products, their manufacturers, or their suppliers in this publication does not imply or connote approval or disapproval of the product by Argonne National Laboratory or the U. S. Department of Energy. 
ARGONNE NAT IONAL LABORATORY

9700 South Cass Avenue

Argonne, Illinois 60439

\title{
MASTER
}

COMPARATIVE STUDY. OF WORKंING FLUIDS

FOR OTEC POWER PLANTS

\section{by}

\author{
E.N. Ganic* and J. Wu \\ Department of Energy Engineering \\ University of Illinois at Chiçago Circle \\ Chicago, Illinois 60680 \\ *Consultant to Components Technology Division \\ Argonne National Laboratory
}

January 1979

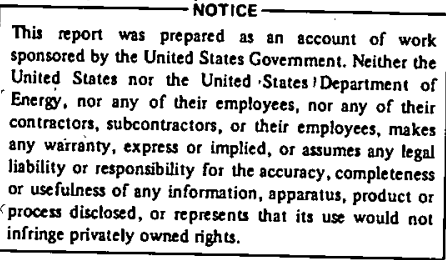

process disclosed, or represents
infringe privately owned rights.

The Argonne Ocean Thermal Energy Conversion Program

is a joint effort of the

Energy and Environmental Systems Division

and Components Technology Division

sponsored by

U.S. Department of Energy

Division of Central Solar Technology 
National Technical Information Service 5285 Port Royal Road

Springfield, Virginia 22161 
NOMENCLATURE . . . . . . . . . . . . . . . . . . . . . . . vi ABSTRACT . . . . . . . . . . . . . . . . . . . . 1

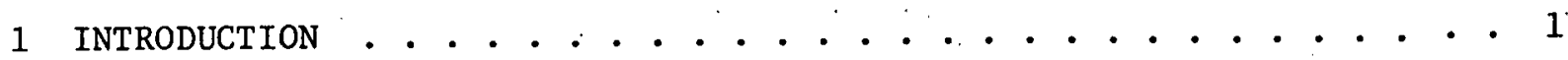

2 WORKING FLUTD . . . . . . . . . . . . . . . . . . . . . 4

3 HEAT TRANSFER IN SHELL-AND-TUBE

HEAT EXCHANGERS FOR OTEC . . . . . . . . . . . . . . . . . 10

4 MODELING OF THE. OTEC SYSTEM . . . . . . . . . . . . . . . . 16

4.1 System Components and Operating Parameters . . . . . . . . . . 16

4.2 Computer Program . . . . . . . . . . . . . . . . . 18

4.3 Enhancement Analysis . . . . . . . . . . . . . . 19

5 RESULTS . . . . . . . . . . . . . . . . . . . 22

5.1 Performance of the 1 MWe OTEC System . . . . . . . . . . . 22

5.2 Performance of the 25 MWe OTEC System . . . . . . . . . . 24

6 ENTRAINMENT AND STATIC HEAD PENALTY . . . . . . . . . . . . . . 28

7 CONCLUDING REMARKS . . . . . . . . . . . . . . . . . . 31 REFERENCES . . . . . . . . . . . . . . . . . . . . • 33 ACKNOWLEDGMENTS . . . . . . . . . . . . . . . . . . . 36 APPENDIX . . . . . . . . . . . . . . . . . . . . 37 
1 Physical Properties of Ammonia, Propane, and Freon-114 : . . . . . 6

2 Physical Properties of Ammonia, Propane, and Freon-114 at $70^{\circ} \mathrm{F}$ and $50^{\circ} \mathrm{F}$. . . . . . . . . . . . . . . . 7

3 Combinations of She11-and-Tube Heat Exchangers for OTEC . . . . . 16

4 Basic OTEC Operating Parameters . . . . . . . . . . . . . 17

\section{LIST OF FIGURES}

1 Schematic of an OTEC System . . . . . . . . . . . . . . 3

2 Saturation Pressure versus Temperature Curves for Some OTEC Working Fluids . . . . . . . . . . . . . . . . . 9

3 Various Heat Transfer Processes on the Shell-Side of OTEC Heat Exchangers . . . . . . . . . . . . . . . . . 15

4 Simplified Computer Program Flow Chart . . . . . . . . . . . 21

5 Case 1: Variation of $\mathrm{A} / \mathrm{W}_{\text {net }}$ as a Function of Shel1-Side Enhancement ....... . . . . . . . . . . . 25

6 Case 1: Variation of $\mathrm{A} / \mathrm{W}_{\text {net }}$ as a Function of Shell-Side and Tube-Side Enhancement ................ 25

7 Case 1: Variation of $\mathrm{A} / \mathrm{W}_{\text {net }}$ as a Function of Tube-Side Enhancement . . . . . . . . . . . . . . . 25

8 Case 2: Variation of $\mathrm{A} /$ Wnet as a Function of Shell-Side Enhancement . . . . . . . . . . . . . . . . 26

9 Case 2: Variation of $A / W_{\text {net }}$ as a Function of She11-Side and Tube-Side Enhancement . . . . . . . . . . . . . 26

10. Cases $3 a$ and $3 \mathrm{~b}:$ Variation of $\mathrm{A} / \mathrm{W}_{\text {net }}$ as a Function of Tube-Side Enhancement . . . . . . . . . . . . . . . . 26

11 Cases 4a and 4b: Variation of $\mathrm{A} / \mathrm{W}_{\text {net }}$ as a Function of Tube-Side Enhancement . . . . . . . . . . . . . . . . 26

12 Case 5: Variation of $\mathrm{A} / \mathrm{W}_{\text {net }}$ as a Function of She11-Side Enhancement . . . . . . . . . . . . . . . . 27

13 Case 5: Variation of $\mathrm{A} / \mathrm{W}_{\text {net }}$ as a Function of She11-Side and Tube-Side Enhancement . . . . . . . . . . . . . . 27

14 Vapor Velocity versus Sprayed-Bundle Radius . . . . . . . . . . . 29

15 Change of Saturation Temperature with Flooded-Bundle Depth (Extrapolation) . . . . . . . . . . . . . . 30

A.1 Case 1: Variation of $\mathrm{A} / \mathrm{W}_{\text {net }}$ as a Function of She11-Side Enhancement . . . . . . . . . . . . . . . . 38

A.2 Case 1: Variation of $\mathrm{A} / \mathrm{W}_{\text {net }}$ as a Function of Shell-Side and Tube-Side Enhancement 38 
A. 3 Case 2: Variation of $\mathrm{A} / \mathrm{W}_{\text {net }}$ as a Function of She11-Side Enhancement . . . . . . . . . . . . . . . . 38

A.4 Case 2: Variation of $A / W_{\text {net }}$ as a Function of She1l-Side and Tube-Side Enhancement . . . . . . . . . . . . 38

A.5 Cases $3 a$ and $3 \mathrm{~b}$ : Variation of $\mathrm{A} / \mathrm{W}_{\text {net }}$ as a Function of Tube-Side Enhancement . . . . . . . . . . . . . . . 39

A.6 Cases 4a and 4b: Variation of $A / W_{\text {net }}$ as a Function of Tube-Side Enhancement . . . . . . . . . . . . . . 39

A.7 Case 5: Variation of $A / W_{n e t}$ as a Function of Shell-Side Enhancement .. . . . . . . . . . . . . . . . . 39

A.8 Case 5: Variation of $A / W_{\text {net }}$ as a Function of Shell-Side and Tube-Side Enhancement .. . . . . . . . . . . . 39 
A Total heat transfer area of evaporator and condenser, $\mathrm{ft}^{2}$

Cp Specific heat, $B t u / 1 b_{m} \cdot{ }^{\circ} \mathrm{F}$

D Tube diameter, ft

f Friction factor

$g \quad$ Gravitational acceleration, $\mathrm{ft} / \mathrm{hr}^{2}$

G Mass $\mathrm{flux}, 1 \mathrm{~b}_{\mathrm{m}} / \mathrm{hr} \cdot \mathrm{ft}^{2}$

h Heat transfer coefficient, Btu/hr $\cdot \mathrm{ft}^{2} \cdot{ }^{\circ} \mathrm{F}$

$\mathrm{h}_{\mathrm{c}}$ Fully developed heat transfer coefficient, Eqs. 4 and $6, \mathrm{Btu} / \mathrm{hr} \cdot \mathrm{ft}^{2} \cdot{ }^{\circ} \mathrm{F}$

$h_{d}$ Average heat transfer coefficient in developing region, Eq. 2, $\mathrm{Btu} / \mathrm{hr} \cdot \mathrm{ft}^{2} \cdot{ }^{\circ} \mathrm{F}$

$i_{f g}$ Latent heat of vaporization, $B t u / 1 b_{m}$

k Thermal conductivity, $\mathrm{Btu} / \mathrm{hr} \cdot \mathrm{ft} \cdot{ }^{\circ} \mathrm{F}$

L Tube length, ft

$\mathrm{L}_{\mathrm{d}} \quad$ Thermal developing length, Eq. 3, ft

$\mathrm{L}_{t r}$ Length of the laminar flow regime, $\mathrm{ft}$

$1 b_{f} 1 b$ force

$1 b_{m} \quad 1 b$ mass

P Pressure; psi

Pr Prandtl number

q Heat $\mathrm{flux}, \mathrm{Btu} / \mathrm{hr} \cdot \mathrm{ft}^{2}$

$\operatorname{Re}_{\Gamma}$ Reynolds number $\left(=4 \Gamma_{f} / \mu_{f}\right)$

$\mathrm{S}$ Entropy, $\mathrm{Btu} / 1 \mathrm{~b}_{\mathrm{m}}{ }^{\circ} \mathrm{F}$

$\mathrm{T}$ Temperature, ${ }^{\circ} \mathrm{F}$

$\mathrm{T}_{\mathrm{b}} \quad$ Boiler saturation temperature, ${ }^{\circ} \mathrm{F}$

$\mathrm{T}_{\mathrm{c}}$ Cold seawater temperature, ${ }^{\circ} \mathrm{F}$

$\mathrm{T}_{\mathrm{cn}}$ Condenser saturation temperature, ${ }^{\circ} \mathrm{F}$

$\mathrm{T}_{\mathrm{h}}$. Hot seawater temperature, ${ }^{\circ} \mathrm{F}$

$\mathrm{v}$ Specific volume, $\mathrm{ft}^{3} / 1 \mathrm{~b}_{\mathrm{m}}$

$\mathrm{V}$ Seawater tube-side velocity, ft/hr

W Work, Btu

$\Delta \mathrm{T}_{\mathrm{w}} \mathrm{T}_{\text {sat }}-\mathrm{T}_{\mathrm{w}},{ }^{\circ} \mathrm{F}$

$\Gamma_{\text {av }}$ Average flow rate $\left[=(1 / L) \quad \int_{0}^{L} \Gamma_{f} d L\right], 1 b_{m} / h r \cdot f t$ 


\section{GREEK LETTERS}

$\alpha \quad$ Thermal diffusivity, $\mathrm{ft}^{2} / \mathrm{hr}$

$\nu \quad$ Kinematic viscosity, $\mathrm{ft}^{2} / \mathrm{hr}$

$\mu$, Dynamic viscosity, $1 \mathrm{~b}_{\mathrm{m}} / \mathrm{hr} \cdot \mathrm{ft}$

$n$ nensity, $1 \mathrm{~h} / \mathrm{ft} \mathrm{t}^{3}$

$\sigma \quad$ Surface tension, $1 b_{f} / f t$

$\varepsilon \quad$ Enhancement multiplier

$\Gamma \quad$ Flow rate, $1 b_{\mathrm{m}} / \mathrm{hr} \cdot \mathrm{ft}$

SUBSCRIPTS

c cold, critical

$f \quad$ liquid

g gas

h hot. (hot seawater)

net net

sat saturation

w wall 


\section{COMPARATIVE STUDY OF WORKING FLUIDS \\ FOR OTEC POWER PLANTS}

by

E.N. Ganic and J. Wu

\section{ABSTRACT}

This report analyzes the effect of three different working fluids (ammonia, propane, and freon-114) on the size of OTEC heat exchangers. Seven different combinations of shell-and-tube heat exchangers are considered. For each combination, a simple computer model of the OTEC power system is used to compare the three fluids. The comparison is made on the basis of $A / W_{n e t}$, where $A$ is the total heat transfer area (evaporator plus condenser) and $W_{\text {net }}$ is the net power output of the plant. Overall, ammonia is shown to be the best fluid (i.e., it yields the lowest value of $A / W_{\text {net }}$ ), a1though in some cases only by a small margin. The thermophysical property that gives ammonia its general superiority is its relatively high thermal conductivity. The report also discusses heat exchanger design problems associated with liquid entrainment and boiling liquid superheat.

\section{INTRODUCTION}

Early feasibility studies have established that an electrical power plant based on a closed Rankine cycle and driven by the ocean thermal difference can serve as a very significant source of energy. However, the efficiency of this cycle is low (due to the small overall temperature difference), and exchangers capable of handling very large heat duties are therefore needed. Such exchangers are very expensive; they are the most costly components in Ocean Thermal Energy Conversion (OTEC) plants.

A schematic of a closed-cycle OTEC power plant is shown in Fig. 1. Major components include the condenser, the evaporator, the turbine, the warm and cold seawater pumps, the working fluid pump, and the cold water delivery pipe. The working fluid enters the evaporator, where it is vaporized. The saturated vapor is then fed to the turbine, and work is extracted. After leaving the turbine, the working fluid enters the condenser. Finally, the condensate is pumped back to the evaporator to complete the cycle. 
The working fluid in an OTEC power plant is an important design parameter; its selection can have a major effect on overall system feasibility and performance. The primary purpose of this study was to compare the effect of three different working fluids (ammonia, propane, and freon-114) on heat exchanger size and system performance. Another objective was to identify those thermophysical properties of the working fluid that have the greatest impact on system performance. The approach taken was to consider seven hypothetical OTEC plants, each with a different type of evaporator/condenser combination. For each of the seven cases, a simple power system model was used to compare the effect of the three working fluids on the basis of $\mathrm{A} / \mathrm{W}_{\text {net }}$, where $A$ is the total heat transfer area (evaporator plus condenser) and $W_{\text {net }}$ is the net power output. Values of $A / W_{\text {net }}$ were obtained for 1 MWe and 25 MWe OTEC systems. Since the heat exchangers are the most expensive items in an OTEC plant, the parameter $A / W_{\text {net }}$ is a significant indicator of overall plant cost. Of course, it is recognized that the ultimate selection of a working fluid will depend on additional factors not rigorously considered in the model (e.g., piping, turbines, working fluid cost, environmental impact, etc.). Nevertheless, despite the simplicity and limitations of the modeling, a number of significant trends were identified. 


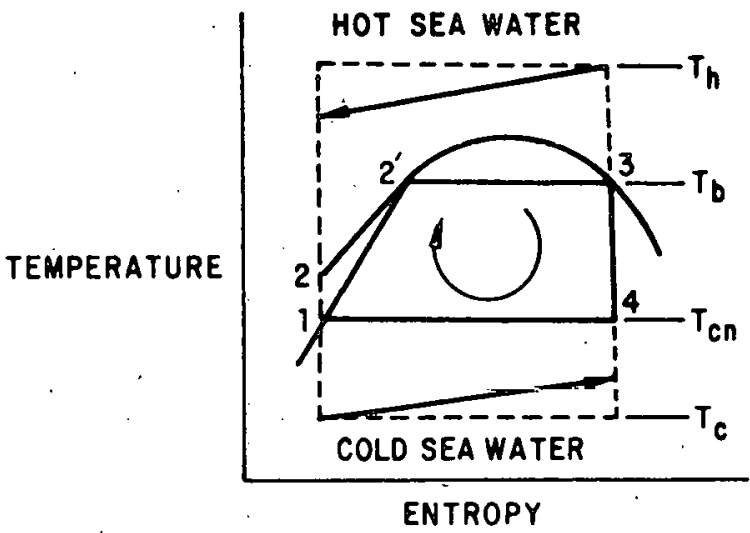

TEMPERATURE - ENTROPY DIAGRAM OF THE OTEC CYCLE

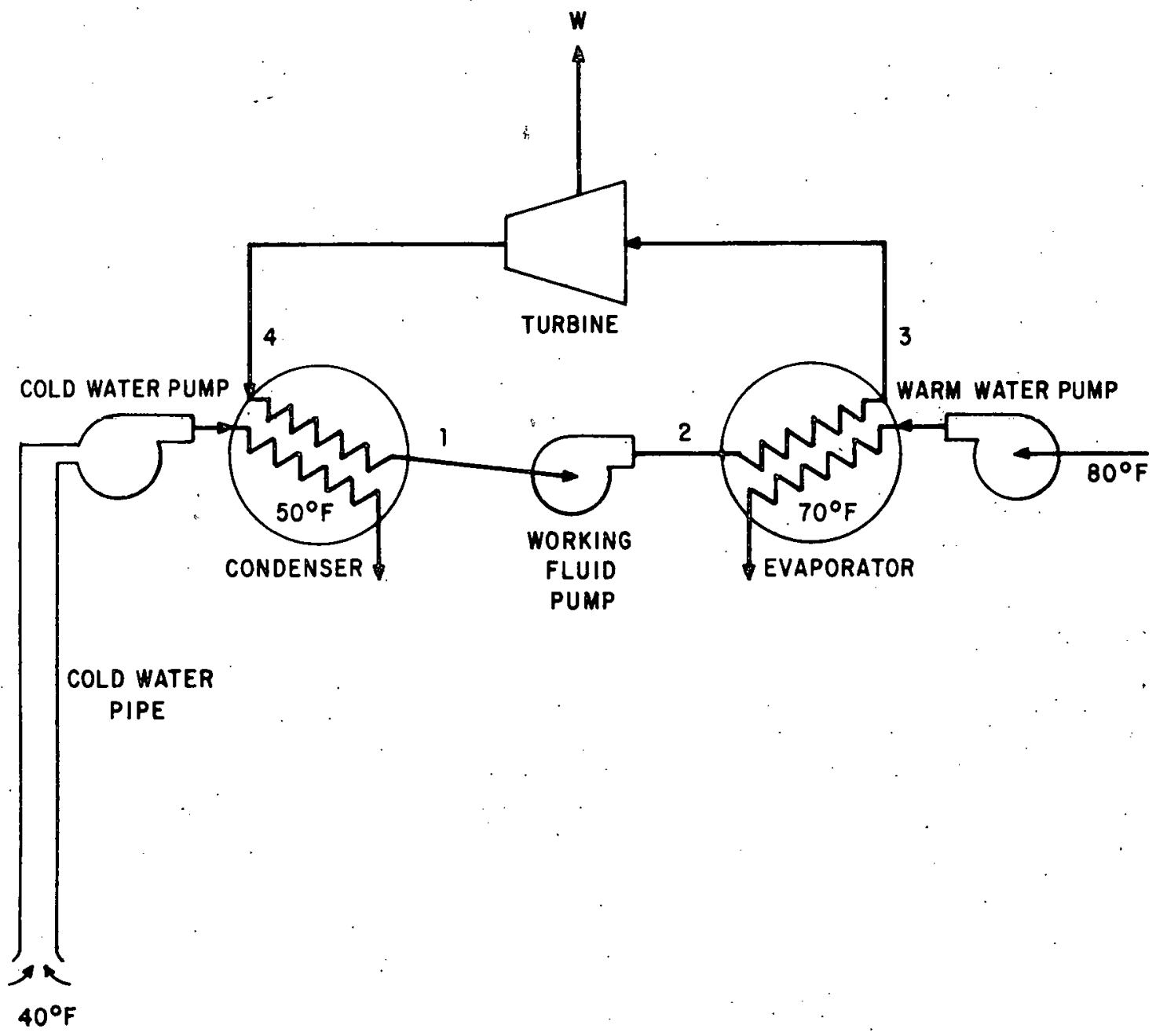

Fig. 1. Schematic of an OTEC System 


\section{WORKING FLUID}

The working fluid for a phase-change cycle like that found in an OTEC power plant has the following desirable characteristics:

1. Critical temperature well above the highest temperature that can be used in the cycle. This makes it possible to vaporize the working fluid and thus add a considerable amount of heat to it at the maximum temperature.

2. Neither very high nor very low saturation pressures at the maximum and minimum temperatures of the cycle. Very high pressures introduce strength problems; very low pressures introduce problems of sealing against infiltration of the atmosphere.

3. Triple point below the expected minimum ambient temperature. This insures that the fluid will not solidify at any point in the cycle nor while being handled outside the cycle.

4. Large latent heat of vaporization. This property affects the amount of fluid circulated and, therefore, the size of the auxiliary piping and equipment. However, it must be considered along with other properties, such as the spccific heat of the liquid and the density of the vapor.

5. Low vapor and liquid specific volumes. These properties affect the heat transfer rates in the heat exchangers. However, when multiplied by the flow rate, the vapor specific volume relates directly to the size of the turbine.

6. High thermal conductivity of the liquid. This property determines the heat transfer rates in the heat exchangers, especially when the working fluid is in the thin-film laminar flow regime as described in a later section.

7. Low value of the specific heat of the liquid. If this value is high, a large amount of cooling is required for the hot fluid entering the evaporator. This is 
further explained in item 9 below.

8. Low value of the liquid wiscosity. This insures that the working fluid pressure drops in the auxiliary piping are low and that the heat transfer rates in the heat exchangers are high.

9. A high ratio of $i_{f g}$ to $C p$ of the liquid so that most of the heat is added at the maximum cycle temperature.

10. A high ratio of $i_{f g}$ to $v_{g}$ of the vapor. This property $\left(i_{f g} / v_{g}\right)$ indicates the quantity of heat transferred by the fluid per unit volume. It affects the size of the cycle components and also the liquid entrainment rate on the shell-side of the heat exchangers, as explained in Sec. 6 .

11. A low value of working fluid molecular weight. This property is directly related to the vapor spectfic volume.

12. A rapidly decreasing saturation vapor line, on a $\mathrm{T}-\mathrm{S}$ diagram, in the region between the maximum and minimum cycle temperatures. This prevents excessive moisture in the turbine exhaust, and insures that all the heat rejection occurs at the minimum cycle temperature.

13. Nontoxicity.

14. Nonflammability/nonexplosiveness.

15. Compatibility with common system materials.

16. Chemical stability over the working fluid temperature range.

17. Low cost and ready availability.

No fluid has all these desirable characteristics. Without detailed cycle analysis, one cannot accurately estimate the effect of a particular characteristic, listed above, on the thermodynamic performance of the cycle and on system feasibility.

Figure 2 shows the saturation pressure versus temperature relations for the three fluids analyzed in this study. The minimum and maximum temperatures of the working fluid are $50^{\circ} \mathrm{F}$ and $70^{\circ} \mathrm{F}$, respectively. One can see 
that the pressure lines for ammonia and propane are almost identical in the temperature range of interest. Therefore, the pressure in the system components will be approximately the same for both fluids. The values of evaporator pressure for ammonia and propane (129 psia and 125 psia, respectively) represent closely the upper limit of acceptable pressure in the OTEC system, since the heat exchangers involved are very large. However, the properties of ammonia and propane are very different, as shown in Tables 1 and 2 . In the temperature range of interest, the saturation pressures of freon-114 (27 psia and 18 psia, evaporator and condenser pressures, respectively) represent almost the lower limit of acceptable pressure in the OTEC system. Properties of freon-114 are considerably different from those of ammia and propane.

After analyzing the T-S data [1]* in the temperature range of $70-50^{\circ} \mathrm{F}$, it was concluded that all three fluids have saturation lines very close to the turbine expansion path (assuming the same turbine design). However, freon-114 and propane are superior to ammonia in this respect.

Table 1. Physical Properties of Ammonia, Propane, and Freon-114

\begin{tabular}{|c|c|c|c|}
\hline Properties & $\begin{array}{l}\text { Ammonia } \\
\left(\mathrm{NH}_{3}\right)\end{array}$ & $\begin{array}{l}\text { Propane } \\
\left(\mathrm{C}_{3} \mathrm{H}_{8}\right)\end{array}$ & $\begin{array}{l}\text { Freon-114 } \\
\left(\mathrm{C}_{2} \mathrm{Cl}_{2} \mathrm{~F}_{4}\right)\end{array}$ \\
\hline Molecular Weight & 17.03 & 44.10 & 170.94 \\
\hline $\begin{array}{l}\text { Boiling Point at } 1 \text { atm } \\
\left({ }^{\circ} \mathrm{F}\right)\end{array}$ & -28 & -43.73 & 38.4 \\
\hline $\begin{array}{l}\text { Freezing Point } \\
\left({ }^{\circ} \mathrm{F}\right)\end{array}$ & -107.9 & -305.8 & -137 \\
\hline $\begin{array}{c}\text { Critical Temperature } \\
\left({ }^{\circ} \mathrm{F}\right)\end{array}$ & 271.4 & 206.3 & 294.3 \\
\hline $\begin{array}{l}\text { Critical Pressure } \\
\text { (psia) }\end{array}$ & 271.4 & 617.4 & 473 \\
\hline $\begin{array}{l}\text { Critical Volume } \\
\left(\mathrm{ft}^{3} / 1 \mathrm{~b}_{\mathrm{m}}\right)\end{array}$ & 0.068 & 0.0728 & 0.0275 \\
\hline
\end{tabular}

Source: [1]

${ }^{a}$ Dich lorotet ra-Fluoroethane.

*Numbers correspond to the list of references. 
With various types of heat exchangers, the properties of the three working fluids that provide the major differences in the relative performance and feasibility of the OTEC cycle are: $i_{f g}, v_{g}, k_{f}, P_{s a t}, C_{f}$, and $\mu_{f}$. Values of $k_{f}$ and $i_{f g}$ for ammonia are very high (Table 2). It is interesting to note that $i_{f g} / v_{g}$ is only $28 \%$ lower for propane than for ammonia. More information about these properties is given later in the report.

Ammonia is a colorless gas at room temperature and is easily detected by its strong odor. It is miscible in all proportions with the hydrazines and water, both separately and in multicomponent combinations. Therefore, its environmental impact is small. By volume, the lower explosive limit of ammonia in air is $16 \%$ and its upper explosive limit is 25\% [1]. Exposure to ammonia vapor concentrations of about $0.5-1 \%$ for about one-half hour

Table 2. Physical Properties of Ammonia, Propane, and Freon-114 at $70^{\circ} \mathrm{F}$ and $50^{\circ} \mathrm{F}$

\begin{tabular}{|c|c|c|c|c|c|c|}
\hline \multirow{2}{*}{$\begin{array}{l}\text { Physical } \\
\text { Properties }\end{array}$} & \multicolumn{2}{|c|}{ Armonia } & \multicolumn{2}{|c|}{ Propane } & \multicolumn{2}{|c|}{ Freon-114 } \\
\hline & $70^{\circ} \mathrm{F}$ & $50^{\circ} \mathrm{F}$ & $70^{\circ} \mathrm{F}$ & $50^{\circ} \mathrm{F}$ & $70^{\circ} \mathrm{F}$ & $50^{\circ} \mathrm{F}$ \\
\hline$\mu_{f}\left(1 b_{m} / h r \cdot f t\right)$ & 0.341 & 0.376 & 0.268 & 0.298 & 0.860 & 0.980 \\
\hline$\mu_{g}\left(1 b_{m} / h r \cdot f t\right)$ & 0.0268 & 0.0258 & 0.021 & 0.019 & 0.0278 & 0.0266 \\
\hline $\mathrm{k}_{\mathrm{f}}^{\circ}\left(\mathrm{Btu} / \mathrm{hr} \cdot \mathrm{ft} \cdot{ }^{\circ} \mathrm{F}\right)$ & 0.2835 & 0.2982 & 0.0576 & 0.0602 & 0.0378 & 0.0395 \\
\hline $\mathrm{k}_{\mathrm{g}}\left(\mathrm{Btu} / \mathrm{hr} \cdot \mathrm{ft} \cdot{ }^{\circ} \mathrm{F}\right)$ & 0.0155 & 0.0140 & 0.0112 & 0.0104 & $0.00588^{a}$ & 0.0055 \\
\hline $\mathrm{Cp}_{\mathrm{f}}\left(\mathrm{Bru} / 1 \mathrm{~b}_{\mathrm{m}} \cdot{ }^{\circ} \mathrm{F}\right)$ & 1.128 & 1.111 & 0.623 & 0.603 & 0.2395 & 0.2334 \\
\hline $\mathrm{Cp}_{\mathrm{g}}\left(\mathrm{Btu} / 1 \mathrm{~b}_{\mathrm{m}} \cdot{ }^{\circ} \mathrm{F}\right)$ & 0.724 & 0.675 & 0.498 & 0.465 & 0.173 & 0.168 \\
\hline$\rho_{f}\left(1 b_{m} / f t^{3}\right)$ & 38 & 39 & 31.2 & 32.2 & 91.6 & 93.7 \\
\hline$\rho_{g}\left(1 b_{m} / f t^{3}\right)$ & 0.43 & 0.30 & 1.17 & 0.87 & 0.87 & 0.61 \\
\hline$i_{f g}\left(B t u / 1 b_{m}\right)$ & 508.6 & 527.3 & 145.7 & 153.2 & 55.8 & 57.6 \\
\hline$i_{f g} / v_{g}\left(B t u / f t^{3}\right)$ & 218.7 & 158.19 & 170.5 & 133.3 & 48.5 & 35.14 \\
\hline$i_{f}\left(B t u / 1 b_{m}\right)$ & 120.5 & 97.9 & 64.2 & 51.8 & 24.4 & 19.7 \\
\hline$i_{g}\left(B t u / 1 b b_{m}\right)$ & 629.1 & 625.2 & 209.9 & 205 & 80.3 & 77.3 \\
\hline$\alpha_{f}\left(f t^{2} / h r\right)$ & 0.00614 & 0.00688 & 0.00296 & 0.00310 & 0.00172 & 0.00181 \\
\hline$\alpha_{g}\left(f t^{2} / h r\right)$ & 0.04979 & 0.06914 & 0.01922 & 0.02571 & 0.03907 & 0.05367 \\
\hline $\mathrm{Pr}_{\mathrm{f}}$ & 1.3568 & 1.4008 & 2.8987 & 2.9849 & 5.4489 & 5.7907 \\
\hline $\mathrm{Pr}_{\mathrm{g}}$ & 1.2518 & 1.2439 & 0.9337 & 0.8495 & 0.8179 & 0.8125 \\
\hline$\sigma \cdot\left(1 b_{f} / f t\right)$ & 0.001462 & 0.001639 & 0.00046 & $0: 000511$ & 0.000868 & 0.000962 \\
\hline$P_{\text {sat }}$ (psia) & 128.80 & 89.190 & 124.683 & 92.185 & 27.261 & 18.534 \\
\hline$P_{\text {sat }}(p s i g)$ & 114.10 & 74.500 & 109.987 & 77.489 & 12.561 & 3.834 \\
\hline
\end{tabular}

Sources: $[1,2]$ :

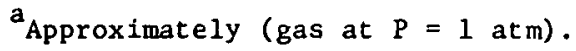


produces serious injury [1]. Ammonia is commonly shipped in tank trucks, rail tank cars, and barges, and is safely transported in long pipelines [3]. The handling and storage methods for ammonia are established technology, and the overall safety record is good.

Propane is a colorless gas at atmospheric pressure and normal temperatures. It has a characteristic natural gas odor, is soluble in ether and alcohol, and is slightly soluble in water. Propane is one of the group of 1iquefied petroleum gases; it is normally shipped in low-pressure cylinders as a liquefied gas under its own vapor pressure at $70^{\circ} \mathrm{F}$. It is flammable at normal temperature. The explosive limits in the air [1] by volume range from 2.3-7.3\%. Propane is much less toxic than ammonia; it is less toxic than carbon dioxide but slightly more toxic than freon-12.

Freon-114 is a colorless, odorless, nonflammable, and nontoxic gas. Exposure to its vapor in concentrations up to about $20 \%$ by volume for about two hours does not appear to produce injury. Since it contains chlorine as a part of the molecule $\left(\mathrm{C}_{2} \mathrm{Cl}_{2} \mathrm{~F}_{4}\right)$, it is readily detectable even in minute amounts. An intense green color indicates.its presence [4] when it is passed through copper gauze kept hot by the essentially colorless flame of burning methyl alcohol.

Other fluids (freon-12, freon-22, butane, and sulfur dioxide) also have suitable vapor pressures for the OTEC cycle, as shown in Fig. 2. These fluids are discussed briefly in Sec. 7. 


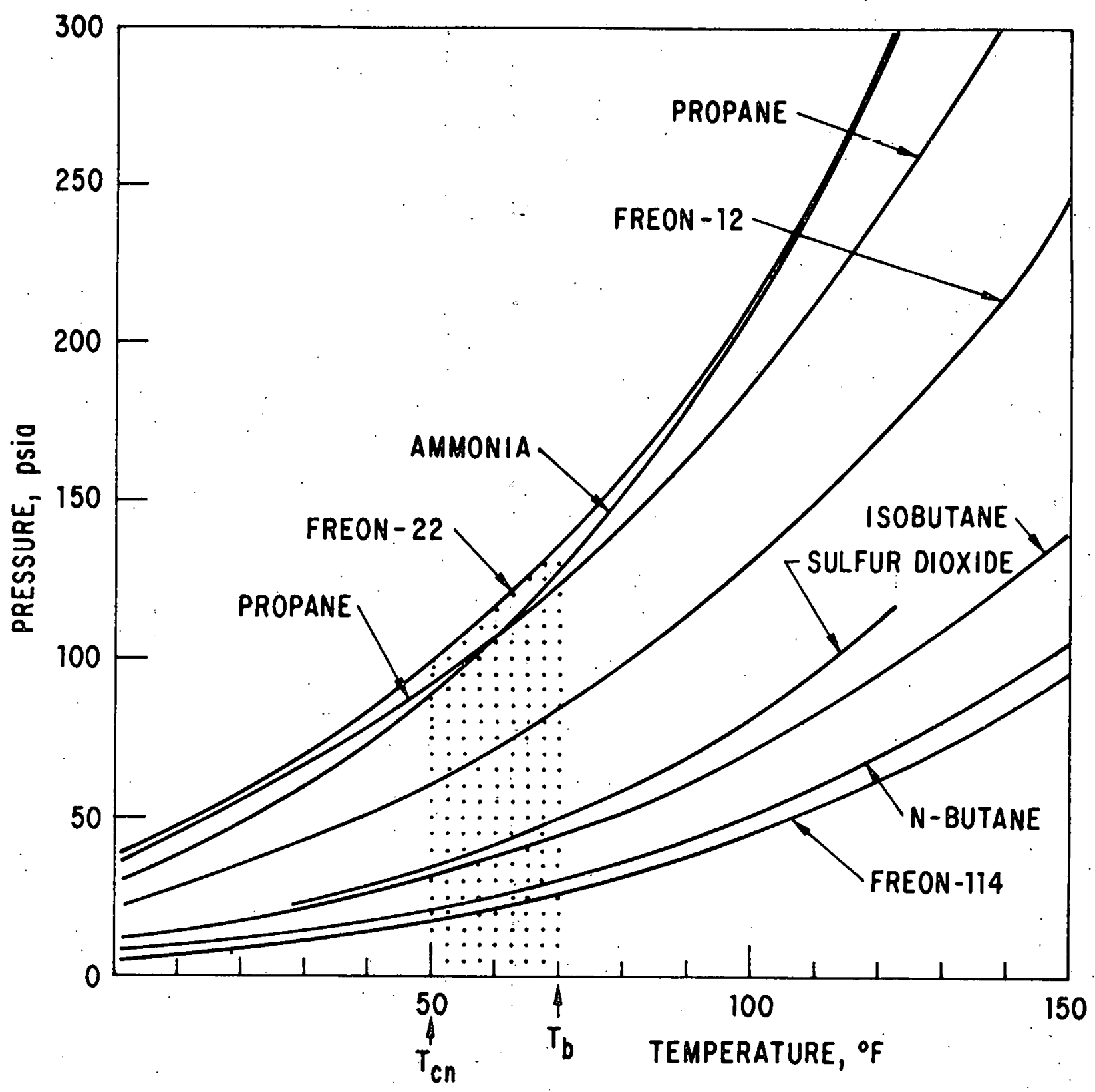

Fig. 2. Saturation Pressure versus Temperature Curves for Some OTEC Working Fluids 
3 HEAT TRANSFER IN SHELL-AND-TUBE HEAT EXCHANGERS FOR OTEC

In shell-and-tube heat exchangers of OTEC plants the working fluid is on the shell side and seawater is on the tube side. The mechanism of heat transfer on the shell side of the evaporator is boiling or thin-film evaporation. The mechanism of heat transfer on the shell side of the condenser is film condensation. In both the evaporator and the condenser, the mechanism of heat transfer on the tube side (seawater side) is forced convection, and it is well predicted by McAdams' correlation [5]. Various heat transfer processes on the shell side of the OTEC heat exchangers are illustrated in Fig. 3 and described below.

A horizontal thin-film evaporation process is shown in Fig. 3a. The liquid film in this case is in the laminar flow regime. The heat transfer coefficient is directly proportional to the liquid conductivity, and it is well predicted by a recent correlation by Lorenz and Yung [6]. In the case of the laminar film this reads:

$$
\mathrm{h}=\mathrm{h}_{\mathrm{d}} \mathrm{L}_{\mathrm{d}} / \mathrm{L}+\mathrm{h}_{\mathrm{c}}\left(1-\mathrm{L}_{\mathrm{d}} / \mathrm{L}\right)
$$

where:

$$
\begin{aligned}
& \mathrm{h}_{\mathrm{d}}=\frac{3}{8} C \mathrm{p}_{\mathrm{f}} \frac{\Gamma_{\mathrm{f}}}{\mathrm{L}_{\mathrm{d}}} \\
& \mathrm{L}_{\mathrm{d}}=\frac{\Gamma_{\mathrm{f}}}{4 \pi \rho_{\mathrm{f}} \alpha_{\mathrm{f}}} \sqrt[3]{\frac{3 \mu_{\mathrm{f}}}{\rho_{\mathrm{f}}^{2} \mathrm{~g}}}
\end{aligned}
$$

and $[6,7]$

$$
h_{c}=0.821\left(\frac{v_{f}^{2}}{k_{f}^{3} g}\right)^{-1 / 3}\left(\frac{4 \Gamma_{f}}{\mu_{f}}\right)^{-0.22}
$$

As shown in [6], the Lorenz-Yung correlation is also applicable if boiling occurs within the thin film. When the thin film is in the turbulent flow regime, i.e.,

$$
\left(\frac{4 \Gamma_{f}}{\mu_{f}}\right)>5800\left(\frac{\nu_{f}}{\alpha_{f}}\right)^{-1.06}
$$


then $[6,7]$ :

$$
h_{c}=0.0038\left(\frac{\nu_{f}^{2}}{k_{f}^{3} g}\right)^{-1 / 2}\left(\frac{4 \Gamma_{f}}{\mu_{f}}\right)^{0.4}\left(\frac{\nu_{f}}{\alpha_{f}}\right)^{0.65}
$$

A horizontal film condensation process is shown in Fig. 3b. The liquid film is in the laminar flow regime. The heat transfer coefficient is strongly affected by the liquid conductivity and is given by the Nusselt relation [5]:

$$
h=0.728 \sqrt[4]{\frac{g \rho_{f}\left(\rho_{f}-\rho_{g}\right) k_{f}^{3} i_{f g}^{\prime}}{D \mu_{f} \Delta T_{w}}} .
$$

where:

$$
i_{f g}^{\prime}=i_{f g}+\frac{3}{8} C p_{f} \Delta T_{w}
$$

A vertical thin-film evaporation process is shown in Fig. 3c. For each fluid the liquid film can be in the laminar or turbulent flow regime, depending on the critical flow rate (minimum flow rate necessary to wet the surface), the evaporation rate, and the tube length. The heat transfer coefficient for both flow regimes is given by the Chun and Seban correlation [7] (Eqs. 4 and 6$)$, where the transition Reynolds number $\left(4 \Gamma_{f} / \mu_{f}\right)$ is given by Eq. 5. It is important to note that the heat transfer coefficient in the 1aminar flow regime (Eq. 4) is proportional to $k_{f}$, but in the turbulent flow regime it is proportional to $\mathrm{k}_{\mathrm{f}}^{0.35}$. There is a very significant difference in $k_{f}$. for the different fluids considered here (Table 2). Since the liquid flow rate varies along the tube length due to evaporation, the average value of the heat transfer coefficient is based on $\Gamma_{a v}$. The value of $L_{t r}$ (the length of the laminar flow regime) is determined by assuming that the flow rate at the bottom of the vertical tube is equal to the critical flow rate and then calculating the flow rate upstream, based on the evaporation rate given by $\mathrm{Eq}$. 4. When the local value of $\left(4 \Gamma_{f} / \mu_{f}\right)$ reaches the value given by Eq. 5, the laminar flow regime ends. The value of $L_{t r}$ is much higher for ammonia than for propane or freon-114, due to the high value of the latent heat of evaporation.

Film condensation on a vertical tube is shown in Fig. 3d. The first portion of the film $\left(L>L_{t r}\right)$ is in the laminar flow regime, and the heat 
transfer coefficient is given by the Nusselt relation [5]. The heat transfer coefficient in the turbulent flow regime $\left(\operatorname{Re}_{\Gamma}>2000\right)$ is given by the Colburn relation [8]:

$$
h=0.056\left(\frac{4 \Gamma_{f}}{\mu_{f}}\right)^{0.4}\left(\frac{k_{f}^{3} \rho_{f}^{2} g}{\mu_{f}^{2}}\right)^{1 / 3} \operatorname{Pr}_{f}^{1 / 2}
$$

The value of $\mathrm{L}_{\mathrm{tr}}$ is determined as described above, following the film flow rate from the top toward the bottom of the tube.

Pool boiling on a plain horizontal tube is illustrated in Fig. 3e. In order for boiling to occur, certain wall superheat is required. The average boiling heat transfer coefficient for horizontal tube bundles increases with pressure and is usually higher than the nucleate boiling coefficient for a single tube. Presumably convection caused by the vigorous agitation of the two-phase mixture enhances the heat transfer. Clearance between the tubes and the bundle diameter are significant factors; tube layout angle apparently is not [9]. A relatively simple, reduced pressure correlation is given by Mostinski [10]:

$$
h=0.00658\left(\mathrm{P}_{\mathrm{c}}^{0.69}\right)(\mathrm{q})^{0.7}\left[1.8\left(\mathrm{P} / \mathrm{P}_{\mathrm{c}}\right)^{0.17}+4\left(\mathrm{P} / \mathrm{P}_{\mathrm{c}}\right)^{1.2}+10\left(\mathrm{P} / \mathrm{P}_{\mathrm{C}}\right)^{10}\right]
$$

This is recommended in [9] and applied here to predict the heat transfer coefficient for this case.

Pool boiling on a High-Flux surface is illustrated in Fig. 3f. The surface heat transfer enhancement is made of a porous sintered metal layer that serves as the nucleus for vapor bubble generation, thereby increasing boiling heat transfer. Experience has shown that the High-Flux surface in flooded-bundle evaporators performs according to the pool boiling values. [11]. The boiling coefficients are so large that any contribution from flow convection may be neglected. Considering the pool boiling of High-Flux as a standard, it has also been reported [11] that under falling-film conditions the High-Flux performance is superior to its pool boiling performance at low heat fluxes. It is important to note that for fluids and conditions - considered in this study, the High-Flux boiling coeffictent is practically independent of the liquid's conductivity; perhaps this is due to the intensive microconvection close to the surface. Since the High-Flux boiling heat transfer coefficient is very high, almost all resistance to heat transfer is 
on the water side. Preliminary tests conducted at Argonne National Laboratory using ammonia as the working fluid yielded the value of $\mathrm{h}=3600 \mathrm{Btu} / \mathrm{hr} \cdot \mathrm{ft}{ }^{2} \cdot{ }^{\circ} \mathrm{F}$ for the High-Flux flooded bundle [12].* Data on High-Flux boiling heat transfer with propane and freon-114 were obtained from $[11,13]$.

It is known that the lowest condensing coefficient occurs when the. condensate is spread uniformly over the surface. If a curved interface is created on the surface, then the pressure of the fluid inside the curved interface will be greater than the pressure of the fluid outside the interface by an amount equal to $2 \sigma / \mathrm{r}$, where $\mathrm{r}$ is the radius of curvature of the interface and $\sigma$ is the surface tension. Therefore, the condensate film will be subjected to surface tension forces acting to push it from the crests into the troughs. This results in the major portion of the crest having a very thin film of condensate, which greatly reduces resistance to heat flow through the crest area. Various practical applications of this mechanism were studied in [14]. In all cases, the local heat transfer coefficient of the laminar condensate $\mathrm{film}$ is proportional to $\mathrm{k}_{\mathrm{f}}$. The form of Linde enhancement indicated in Fig. $3 \mathrm{~g}$ is still proprietary, but the condensing coefficient data used here are reported in [15].

The condensate on the horizontal tube begins to drip at a certain film thickness. When condensing and dripping quantities equilibrate, a stable condensing state is reached. Therefore, in order to increase the condensation rate, the dripping should be increased (i.e., the heat transfer surface should have a more suitable structure for dripping [16]). The Hitachi surface, "Thermoexcel-C," has saw-tooth-shaped fins (Fig. 3h). Efficient dripping of the condensate occurs, the liquid film stays thin; and its thermal resistance is quite small. The experimental data for "Thermoexce1-C" are reported in $[16 ; 17]$ :

Various types of heat transfer enhancement on the water side (i.e., tube side) have been suggested [18] for OTEC heat exchangers. Tube-side enhancement, however, results in increased friction losses. To determine whether there is any net benefit in employing a particular type of enhance-

* Subsequent testing at Argonne using ammonia as the working fluid yielded an ammonia-side coefficient of $4800 \mathrm{Btu} / \mathrm{hr} \cdot \mathrm{ft}^{2}{ }^{\circ} \mathrm{F}$ for the High-Flux flooded bundle [31]. This implies a slightly larger overall heat transfer coefficient, and thereby tends to strengthen the argument in favor of ammonia. 
ment, it is necessary to know the relation between the heat transfer coefficient, $h$, and the friction factor, f.

For turbulent flows in tubes, the relation between $h$ and $f$ is given by the Colburn analogy [5]:

$$
\frac{h}{\mathrm{Cp}_{\mathrm{f}} G_{f}} \operatorname{Pr}_{f}^{2 / 3}=\frac{f}{2}
$$




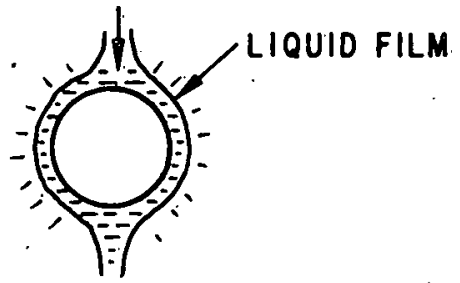

(a) THIN-FILM EVAPORATION (HORIZONTAL TUBE)

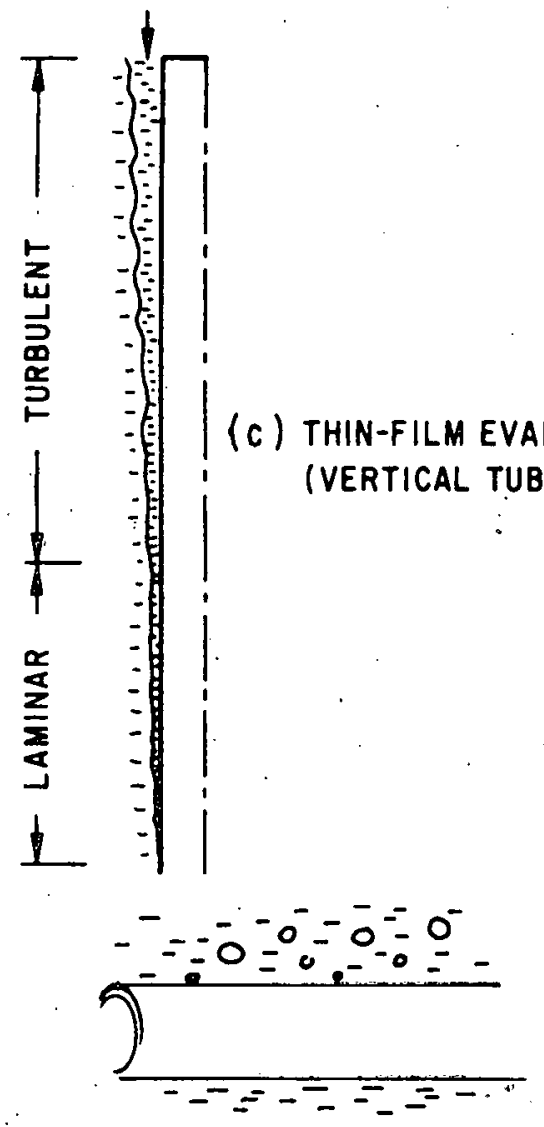

(e) POOL BOILING

(HORIZONTAL, PLAIN TUBE)

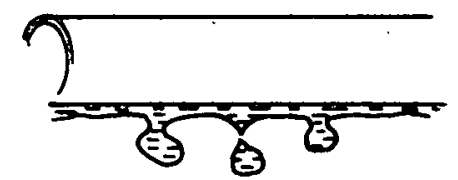

(g) FILM CONDENSATION

(HOR!ZONTAL TUBE, LINDE ENHANÇEMENT NOT SHOWN)

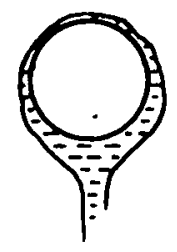

(b) FILM CONDENSATION (HORIZONTAL TUBE)

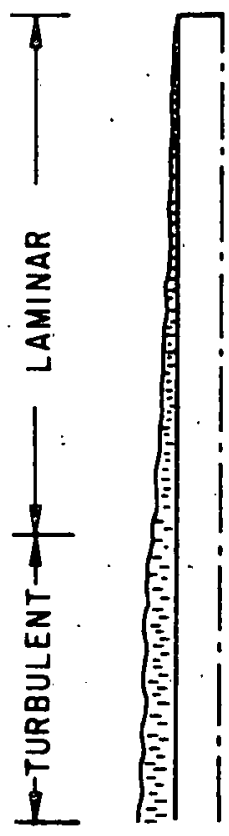

(d') FILM CONDENSATION (VERTICAL TUBE) (f) POOL BOILING (HORIZONTAL, HIGH-FLUX TUBE)

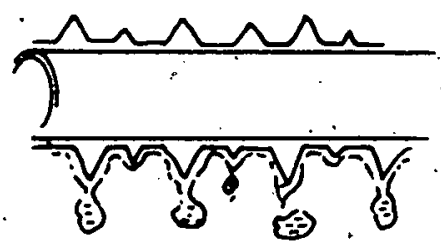

(h) FILM CONDENSATION (HORIZONTAL TUBE, HITACHI ENHANCEMENT)

Fig. 3. Various Heat Transfer Processes on the Shell-Side of OTEC Heat Exchangers 


\subsection{SYSTEM COMPONENTS AND OPËRATING PARAMETERS}

Table 3 1ists the seven combinations of shell-and-tube heat exchangers that were analyzed in this study. The thermal performances of Cases $3 a$ and $3 b$ were assumed to be identical (i.e., the two cases were presumed to require the same heat transfer area for a given heat duty). However, the configurations and design problems of the sprayed- and flooded-bundle evaporators are different [15]. The same is true for the Case $4 \mathrm{a}$ and $4 \mathrm{~b}$ combinations. Further information on heat exchangers considered here is given elsewhere $[15,19]$.

Table 4 lists major operating parameters for this OTEC model. The evaporator and condenser tubes were assumed to be made of titanium and aluminum, respectively.

Table 3. Combinations of Shell-and-Tube
Heat Exchangers for OTEC

\begin{tabular}{lc}
\hline Type of Combination & Case No. \\
\hline Horizontal & \\
Plain-Tube Thin-Film Evaporator & \\
Plain-Tube Thin-Film Condenser & \\
Plain-Tube Pool Boiler & 2 \\
Plain-Tube Thin-Film Condenser & \\
High-Flux-Tube Pool Boiler & $3 \mathrm{a}$ \\
Linde Thin-Film Condenser & \\
High-Flux-Tube Sprayed-Bundle Evaporator \\
Linde Thin-Film Condenser \\
High-Flux-Tube Pool Boiler \\
Hitachi Thin-Film Condenser \\
High-Flux-Tube Sprayed-Bundle Evaporator \\
Hitachi Thin-Film Condenser \\
Vertical \\
$\begin{array}{l}\text { Plain-Tube Thin-Film Evaporator } \\
\text { Plain-Tube Thin-Film Condenser }\end{array}$
\end{tabular}


Table 4. Basic OTEC Operating Parameters

\begin{tabular}{|c|c|}
\hline Paramet er & Value \\
\hline $\begin{array}{l}\text { Warm Seawater Inlet Temperature } \\
\text { Cold Seawater Inlet Temperature } \\
\text { Working Fluid Evaporation Temperature } \\
\text { Working Fluid Condensation Temperature. }\end{array}$ & $\begin{array}{l}80^{\circ} \mathrm{F} \\
40^{\circ} \mathrm{F} \\
70^{\circ} \mathrm{F} \\
50^{\circ} \mathrm{F}\end{array}$ \\
\hline $\begin{array}{l}\text { Outside Tube Diameter } \\
\text { Inside Tube Diameter } \\
\text { Water-Side Fouling Factor } \\
\text { Aluminum Tube Conductivity }\end{array}$ & $\begin{array}{c}1.5 \text { in. } \\
1.44 \text { in. } \\
0.0003 .\left(\mathrm{Btu} / \mathrm{hr} \cdot \mathrm{ft}^{2} .{ }^{\circ} \mathrm{F}\right)^{-1} \\
11.9 \mathrm{Btu} / \mathrm{hr} \cdot \mathrm{ft} \cdot{ }^{\circ} \mathrm{F}\end{array}$ \\
\hline $\begin{array}{l}\text { Titanium Tube Conductivity } \\
\text { Cold Water Pipe Length } \\
\text { Warm Water Pipe Length } \\
\text { Turbine Efficiency }\end{array}$ & $\begin{array}{l}10 \mathrm{Btu} / \mathrm{hr} \cdot \mathrm{ft} \cdot{ }^{\circ} \mathrm{F} \\
2000 \mathrm{ft} \\
100 \mathrm{ft} \\
0.9\end{array}$ \\
\hline $\begin{array}{l}\text { Pump Efficiency } \\
\text { Heat Exchanger Tube Length in } 1 \text { MWe Plant }{ }^{a} \\
\text { Heat Exchanger Tube Length in } 25 \text { MWe Plant } \\
\text { Maximum Shell-Side Pressure Drop across Exchanger }\end{array}$ & $\begin{array}{l}0.8 \\
20 \mathrm{ft} \\
40 \mathrm{ft} \\
1.5 \text { psia }\end{array}$ \\
\hline $\begin{array}{l}\text { Pipe Length between Cycle Components } \\
\text { Liquid Velocity through Pipeb } \\
\text { Vapor Velocity through Pipe } \\
\text { Cold Water Discharge Pipe Length }\end{array}$ & $\begin{array}{l}20 \mathrm{ft} \\
15 \mathrm{ft} / \mathrm{s} \\
50 \mathrm{ft} / \mathrm{s} \\
50 \mathrm{ft}\end{array}$ \\
\hline
\end{tabular}

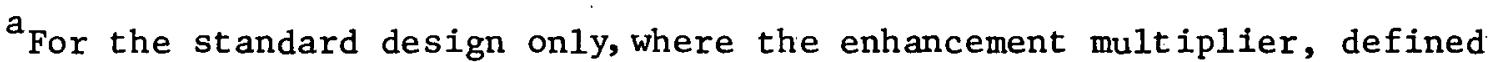
later in the text, was equal to 1 .

$\mathrm{b}$ The pipe diameters for the liquid and vapor lines between cycle components were proportional to $\left(\rho_{f} f_{f g}\right)^{-0.5}$ and $\left(\rho_{g}{ }_{f g}\right)^{-0.5}$, respectively.

The relations used to model the performance of the turbine, the working fluid pump, and the seawater pumps were taken from $[20,21]$. The pressure drop on the cold. water side is made up of pressure drops due to the friction, density head, and change in the kinetic energy of the flow. These losses consist of:

a) The cold water pipe entrance loss,

b) The cold water pipe exit loss,

c) Two elbow losses (an assumed equivalent to the sum of all sudden enlargement and contraction losses in the pipe),

d) Cold water pipe frict.ion losses,

e) Losses due to the variation of water density with depth (i.e., the density head), 
f) Heat exchanger entrance losses (sudden enlargement and contraction),

g) Heat exchanger exit losses (sudden enlargement and contraction), and

h) Friction losses in the heat exchanger tubes.

Likewise, the losses on the warm water side include:

a) The warm water pipe entrance loss,

b) The warm water pipe exit loss,

c) Warm water pipe friction losses,

d) Heat exchanger entrance losses (sudden enlargement and contraction),

e) Heat exchanger exit losses (sudden enlargement and contraction), and

f) Friction losses in the heat exchanger tubes.

The cold water flow rate was determined from the heat duty of the condenser and the cold water temperature drop. Similarly, the warm water flow rate was determined from the heat duty of the evaporator and the warm water temperature drop. The quality of the vapor leaving the turbine was calculated based on an isentropic efficiency of 0.9. A pipe friction factor was calculated from Eq. 4.8 of [5]. Finally, the working fluid properties at the Rankine cycle states were assumed known (Tables 1 and 2).

\subsection{COMPUTER PROGRAM}

In the course of this study, a computer program that simulates the OTEC cycle was developed* based on [22]. The computer program input values are given in Sec. 4.1 (Table 4). At the beginning of the calculation procedure, the cold water pipe velocity, the heat exchanger tube-side velocity, the cold water outlet temperature, and the warm water outlet temperature were estimated. After parametric studies were performed (details of which have already been reported in [22]), the following values for the operating conditions were adopted: cold water pipe velocity of $2 \mathrm{ft} / \mathrm{s}$, heat exchanger tube-side velocity of $6 \mathrm{ft} / \mathrm{s}$, cold water outlet temperature of $43^{\circ} \mathrm{F}$, and warm water outlet temperature of $77^{\circ} \mathrm{F}$.

$*_{A}$ recent computer simulation model for OTEC was also reported in [30]. 
The optimum value of the tube-side velocity (i.e., the value of $V$ for which $\mathrm{A} / \mathrm{W}_{\text {net }}$ has a minimum value) was slightly less than $6 \mathrm{ft} / \mathrm{s}$ for propane and freon-114 and slightly higher than $6 \mathrm{ft} / \mathrm{s}$ for ammonia. For simplicity, the value of $V=6 \mathrm{ft} / \mathrm{s}$ was adopted for all three fluids since $A /$ Wnet was not very sensitive to $V$ in the vicinity of the minimum point (see, for example, Figs. 5 and 6 of [22]).

The basic flow chart of the program is shown in Fig. 4. The program output includes: mass flows of warm and cold water, mass flow of working fluid, pump requirements, net power output, system efficiency, heat exchanger areas necessary for the particular working fluid, and power plant performance measured in $\mathrm{ft}^{2}$ of heat transfer area per net KWe output.

As indicated in Fig. 4, the working fluid mass flow rate is obtained by an iteration procedure. Its initial value is based on the net design output ( 1 MWe or 25 MWe, in the case of this study) and the Carnot efficiency. An alternative procedure for calculating the working fluid mass flow rate is given in [11].

\subsection{ENHANCEMENT ANALYSIS}

This study analyzed the effects of different working fluids on the size (heat transfer area) of the heat exchangers and on power plant performance (measured in $\mathrm{ft}^{2}$ of heat transfer area per net kWe output). The objectives of this analysis were to minimize the total heat transfer area, $A$, and to increase the net work output, $W_{\text {net }}$, for each combination of exchangers. In other words; the goal was to minimize $A / W_{n e t}$ for the systems under consideration.

In order to decrease the heat transfer area of the exchangers, heat transfer enhancement was assumed on the tube side or the shell side or both, depending on the particular case. An enhancement multiplier, $\varepsilon$, was applied to account for all types of enhancement (tube-side, she11-side, or both). For example, when $\varepsilon=2$, the initial heat transfer coefficient relative to a plain tube was doubled. The following procedure was used to generate $A / W_{\text {net }}$ versus $\varepsilon$.

Starting with nominal design conditions, the new heat transfer coefficient and the new heat transfer area were calculated for $\varepsilon>1$. The 
number of tubes was kept constant* (i.e., the same as for the nominal design), and a new tube length was calculated. Since the frictional pressure drop on the tube side is a function of the tube length, the procedure for calculating pressure drops, pumping power, and net output was repeated for values $\varepsilon>1$. When she11-side enhancement was assumed, no pressure drop change was considered. However, for water-side enhancement, the increase in $f$ (friction factor) due to the increase in $h$ (heat transfer coefficient) was calculated using the Colburn relation (Eq. 10).

*Also, the tube-side velocity was kept constant at $6 \mathrm{ft} / \mathrm{s}$ as an antifouling precaution. 


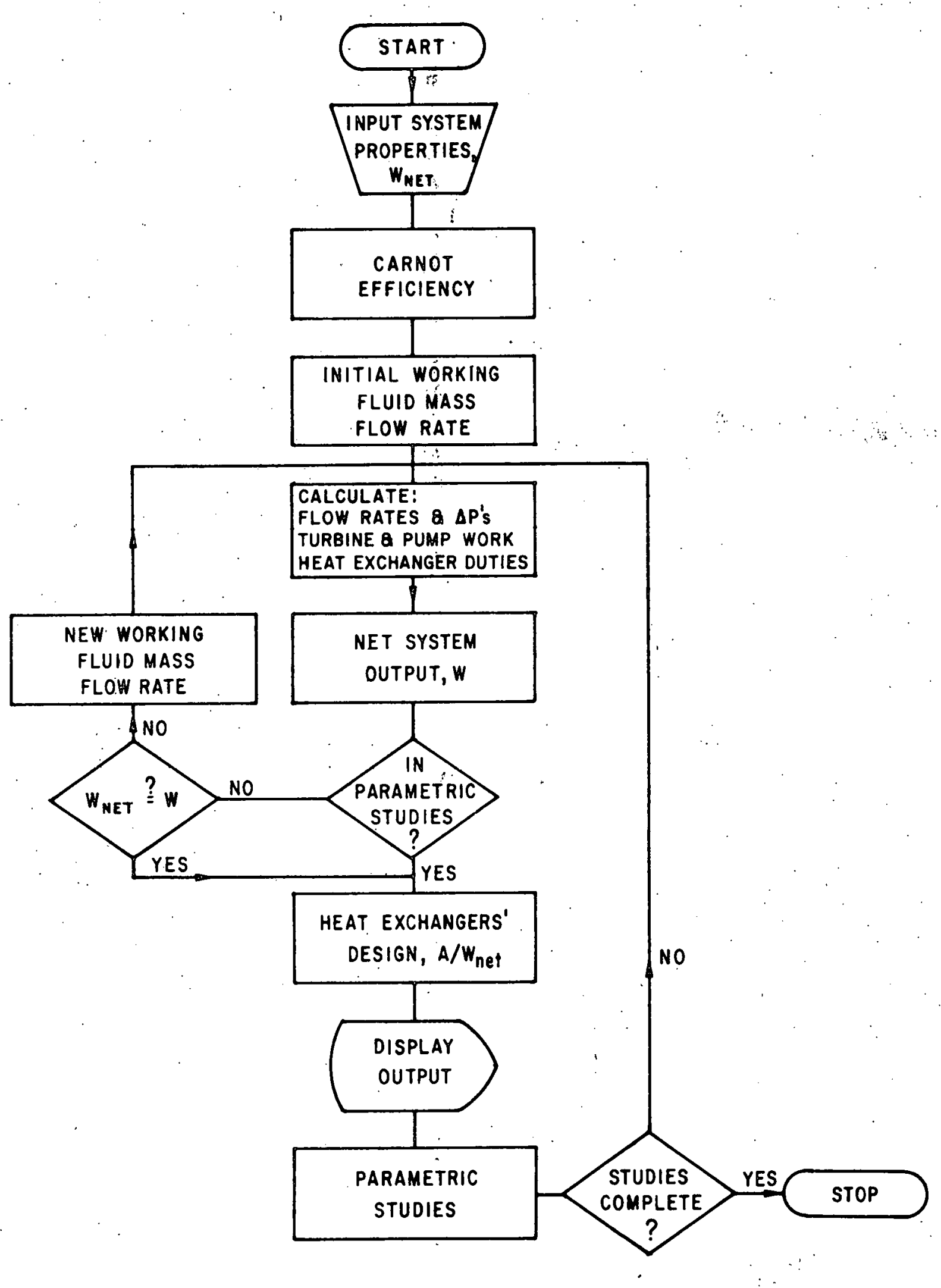

Fig. 4. Simplified Computer Program Flow Chart 


\section{$5 \quad$ RESULTS}

\subsection{PERFORMANCE OF THE I MWE OTEC SYSTEM}

The performance of the 1 MWe OTEC power plant system was analyzed using various combinations of the she11-and-tube heat exchangers listed in Table 3 .

Case 1

This case includes a horizontal thin-film evaporator and a horizontal thin-film condenser. The thin-film heat transfer coefficient (Eq. 1) is about 6.5 times higher for ammonia than for freon-114 and about five times higher for ammonia than for propane. Similarly, the film condensation coefficient is about five times higher for ammonia than for propane and eight times higher for ammonia than for freon-114. The tube-side heat transfer coefficient (based on the seawater velocity of $6 \mathrm{ft} / \mathrm{s}$ ) is much higher than the she11-side heat transfer coefficient for propane and freon-114. Therefore, shell-side enhancement is very desirable for these two fluids.

Fig. 5 shows the variation of $A / W_{\text {net }}$ with shell-side enhancement. Points $A, P$, and $F$ in Fig. 5 represent the performance of the system under standard design conditions $(\varepsilon=1)$. The change in $A / W_{\text {net }}$ for ammonia is small when compared with the other two fluids. Also, freon-114 is shown to be slight1y superior to propane for $\varepsilon>2$, although the latter has a higher shell-side heat transfer coefficient. This is partly due to the greater working fluid pumping power required for propane. The same phenomenon is observed in some other cases. Fig. 6 shows the variation of $A / W_{\text {net }}$ with shell- and tube-side enhancement (where $\varepsilon$ is the multiplier for both the shell and tube heat transfer coefficients). As expected, the enhancement on the tube side is not beneficial for propane and freon-114 (Fig. 7), but it is beneficial for ammonia when $\varepsilon<2$. From Figs. 5-7, it is evident that ammonia is the best fluid for Case 1 because it has the highest thermal conductivity.

It is important to mention that for some specific types of surface enhancement the relation between the tube-side heat transfer coefficient and the friction factor is not necessarily given by Eq. 10. Furthermore, the 
value of the fouling factor may also strongly depend on the type of surface enhancement.

\section{Case 2}

This combination consists of the horizontal plain-tube pool boiler and the thin-film condenser. For all three fluids values of $A / W_{\text {net }}$ are unacceptably high when $\varepsilon=1$ (Figs. 8-9); they are especially high for freon114. Since many uncertainties are associated with required wall superheat for pool boiling on the plain tube under OTEC conditions (low $\triangle T^{\prime}$ 's), these results should be taken with reservation.

\section{Cases $3 a$ and $3 b$}

In these combinations the area of the High-Flux evaporator is the same for all three fluids, since practically all resistance to heat transfer is on the water side. Ammonia is slightly more favorable than propane and freon114 because it yields a higher overall heat transfer coefficient in the condenser and requires less pumping power than the other two working fluids. Freon-114 is superior to propane mostly because of the lower working fluid pumping power requirement. However, the performance of all three fluids measured in terms of $\mathrm{A} / \mathrm{W}_{\text {net }}$ is satisfactory for this system, and the tubeside enhancement is beneficial when $\varepsilon<2$ (Fig. 10). When $\varepsilon>2$, the increase in tube frictional pressure drops increases $A / W_{\text {net }}$.

\section{Cases $4 a$ and $4 b$}

In Cases $4 \mathrm{a}$ and $4 \mathrm{~b}$ the overall heat transfer coefficient and heat transfer area of the evaporator are the same for all three fluids. The overal1 heat transfer coefficient of the condenser is higher for ammonia than for propane and freon-114. Freon-114 is superior to propane mostly because of the lower working fluid pumping power requirement. As shown in Fig. 11, the performance of all three fluids in terms of $A / W_{\text {net }}$ is very good, and the tubeside enhancement is beneficial for $\varepsilon<2.2$.

\section{Case 5}

This combination consists of the vertical thin-film evaporator and thin-film condenser. The performance of this system is illustrated in 
Figs. 12 and 13. As in Case 1, ammonia is the best fluid because of its high thermal conductivity. Comparing Figs. 12 and 13 with Figs. 5 and 6 , one can see that Case 1 has a better performance than Case 5 in terms of $A / W_{n e t}$.

\subsection{PEREORMANCE OF THE 25 MWE OTEC SYSTEM}

Results of performance of the 25 MWe OTEC system were generated by the same procedure used for the 1 MWe system. The pipe lengths between the system components, the water and working fluid velocities, and the efficiencies of the pumps and turbine were the same as for the 1 MWe system. As shown in Table 4, the length of the heat exchanger tubes for the nominal design was $40 \mathrm{ft}$. The results for the 25 MWe system are given in the Appendix (Figs. A.1-A.8). These results are similar to those for the 1 MWe system. The Case 1 results are in reasonable agreement with those reported by Owens [29]. 


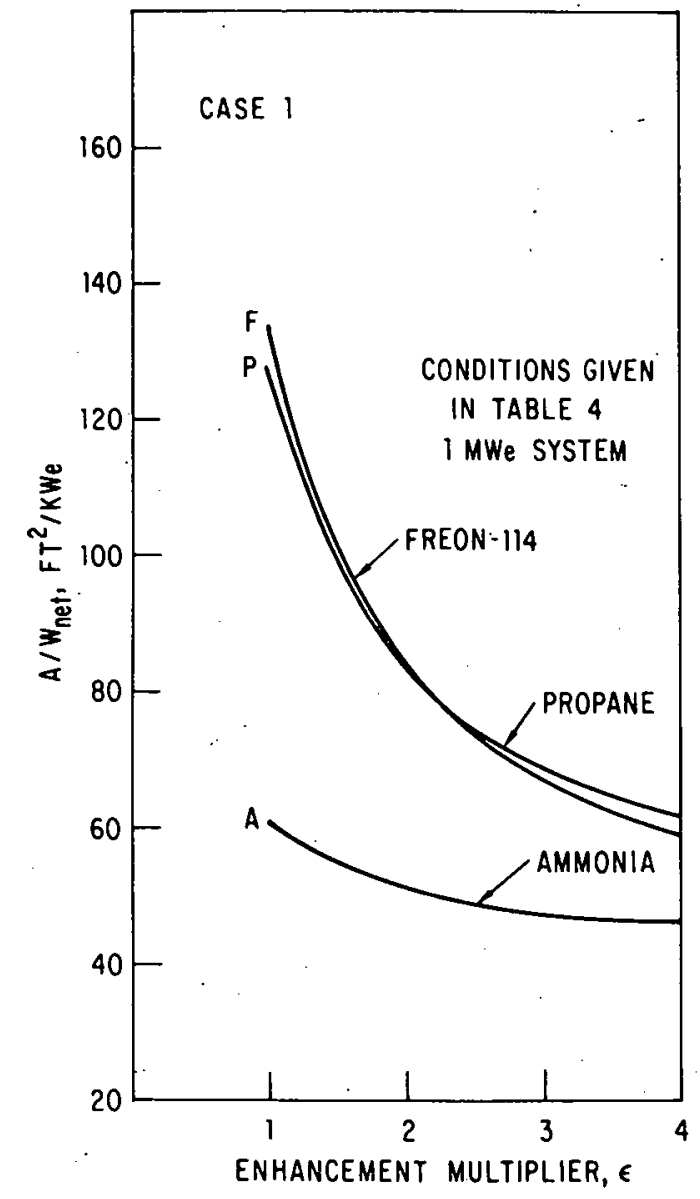

Fig. 5. Case 1: Variation of A/Wnet as a Function of Shel1Side Enhancement

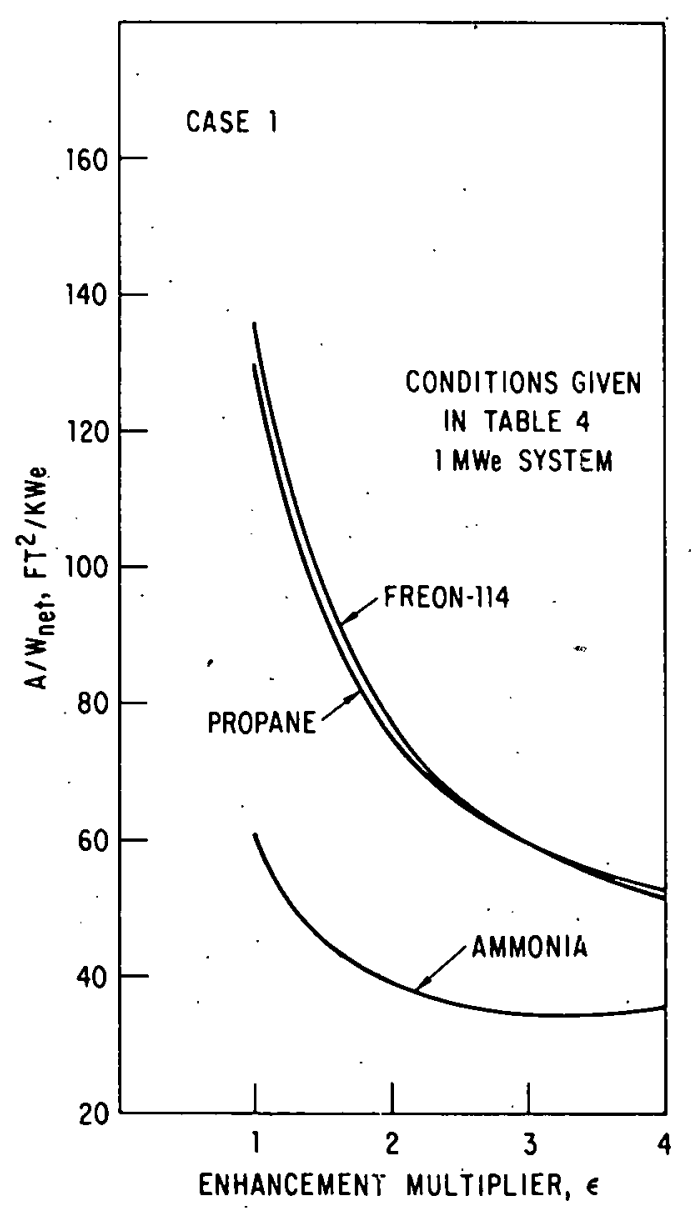

Fig. 6. Case 1: Variation of A./Wnet as a Function of Shel1Side and Tube-Side Enhancement

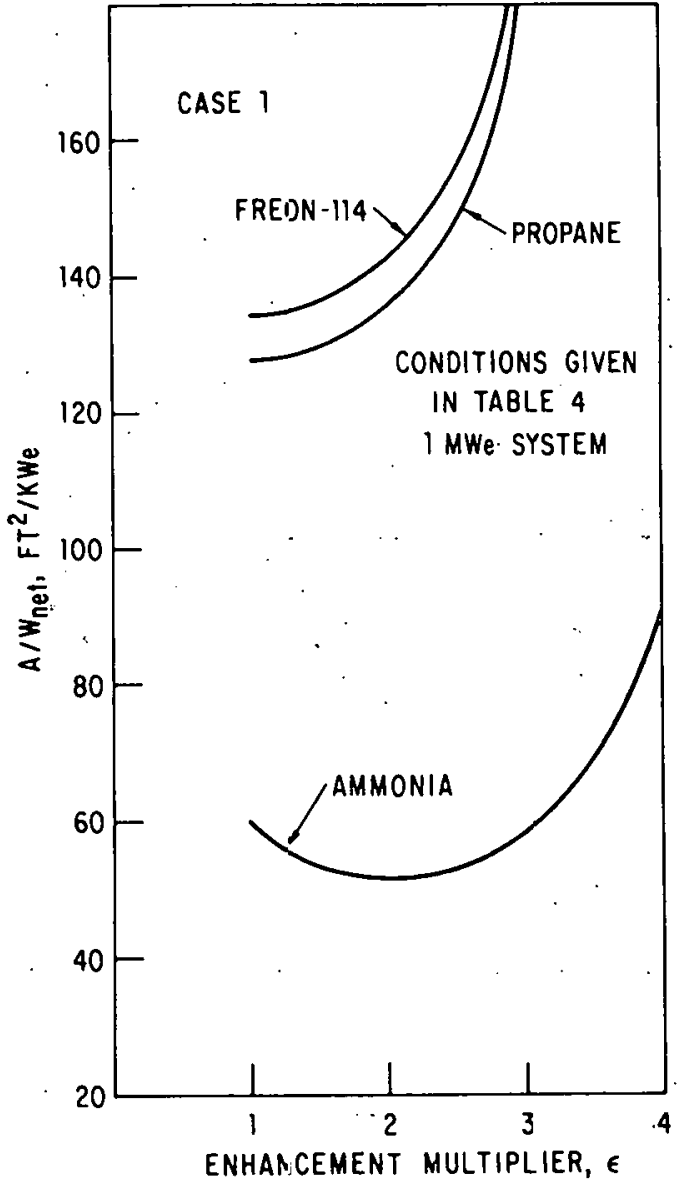

Fig. 7. Case 1: Variation of $A / W_{\text {net }}$ as a Function of TubeSide Enhancement 


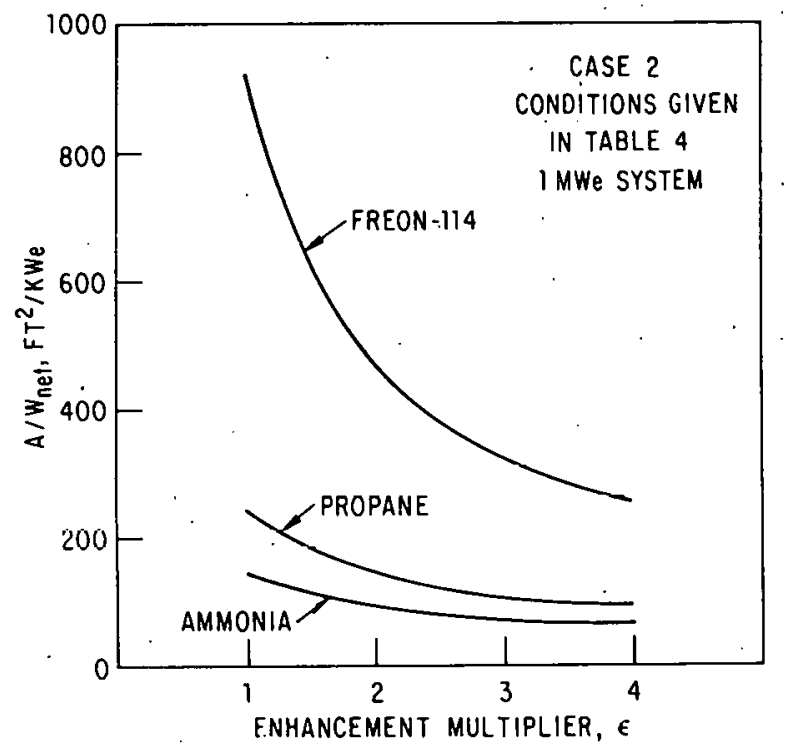

Fig. 8. Case 2: Variation of $\mathrm{A} /$ Wnet as a Function of Shell-Side Enhancement

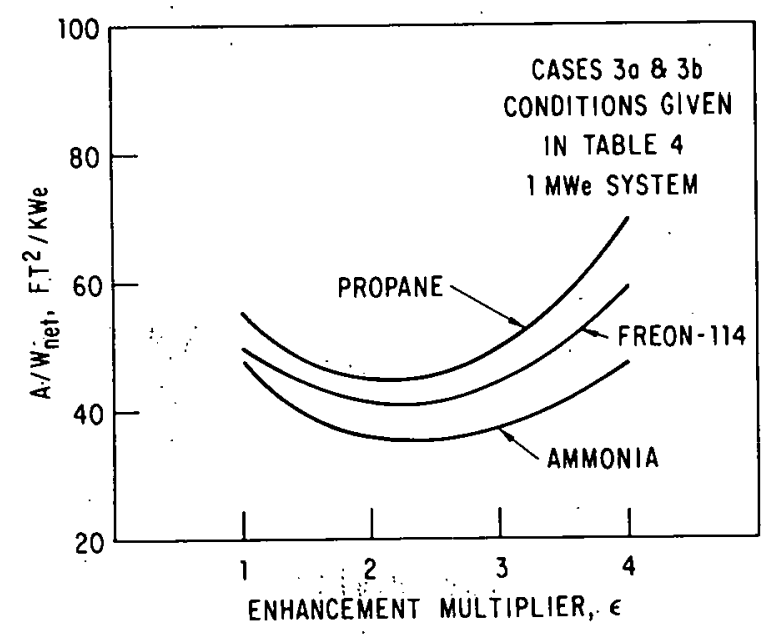

Fig. 10. Cases $3 a$ and $3 b$ : Variation of $A / W_{\text {net }}$ as a Function of Tube-Side Enhancement

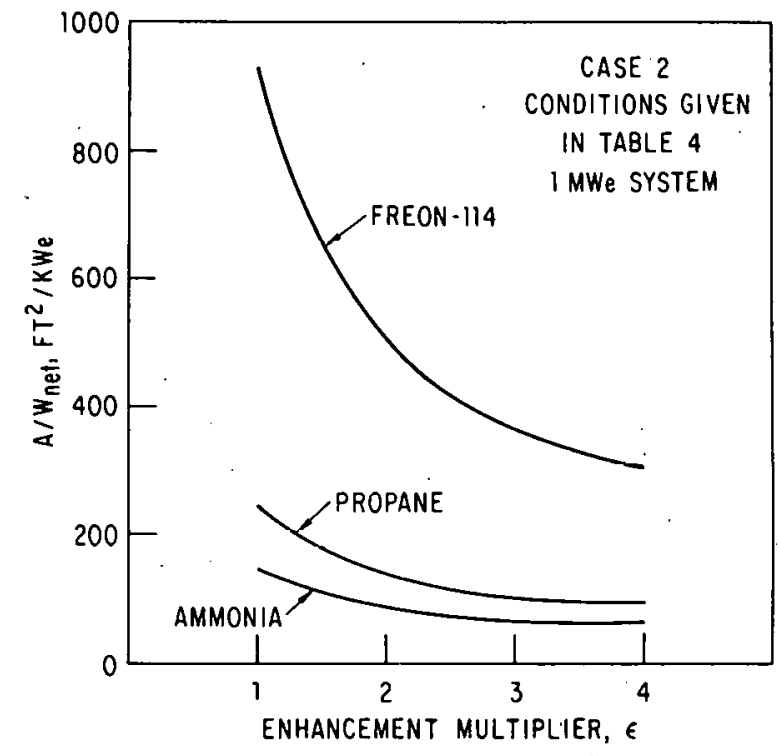

Fig. 9. Case 2: Variation of $\mathrm{A} / \mathrm{W}_{\text {net }}$ as a Function of She11-Side and Tube-Side Enhancement

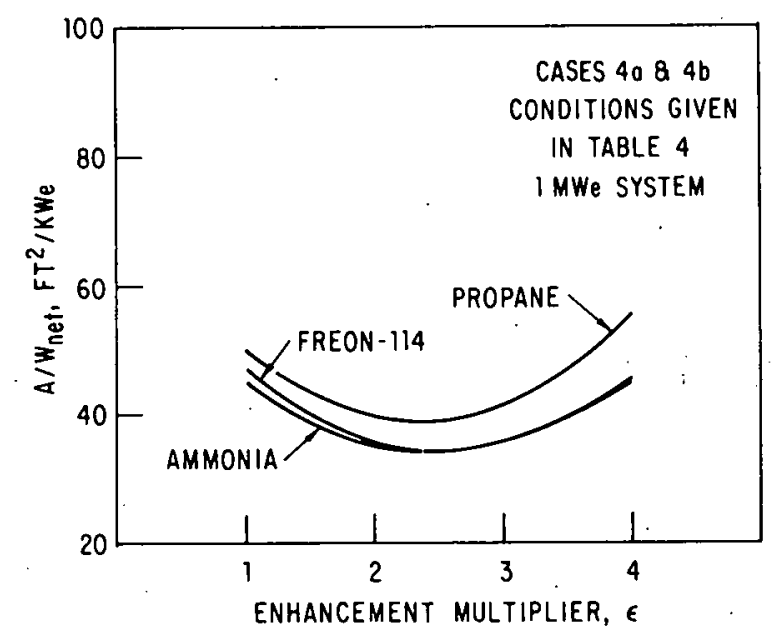

Fig. 11. Cases 4a and 4b: Variation of $A / W_{\text {net }}$ as a Function of Tube-Side Enhancement 

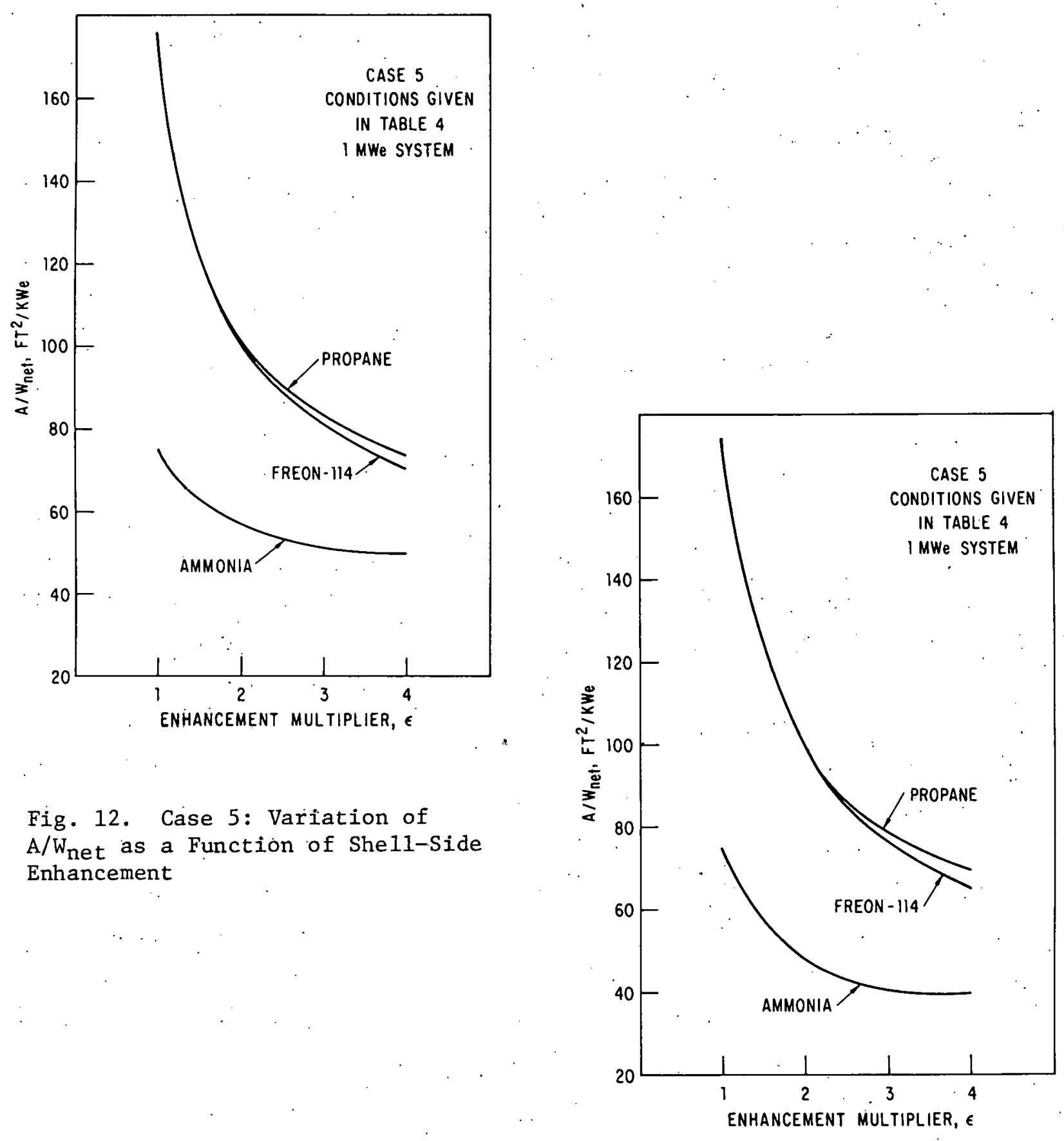

Fig. 12. Case 5: Variation of $\mathrm{A} / \mathrm{W}_{\text {net }}$ as a Function of Shell-Side Enhancement

IN TABLE 4

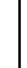




\section{ENTRAINMENT AND STATIC HEAD PENALTY}

There are many problems associated with the design of shel1-and-tube heat exchangers for the OTEC power system. However, two specific problems -liquid entrainment and boiling liquid superheat -- are related to the selection of the working fluid.

Liquid entrainment is a problem that occurs mainly in sprayed-bundle evaporators (horizontal thin-film evaporators), as explained in [23]. At the moderate vapor velocities, deflection of the liquid columns and entrainment of drops occur [24]. As a result, dry regions may form on the shell side. The most important property of the working fluid associated with liquid entrainment is the ratio of enthalpy of vaporization to specific volume of vapor $\left(i_{f g} / v_{g}\right)$. The values of $i_{f g} / v_{g}$ for ammonia, propane, and freon-114 are given in Table 2. In order to illustrate the importance of $i_{f g} / v_{g}$, the vapor velocities on the shell side of the sprayed bundle are given in Fig. 14 for all three fluids. The values of the vapor velocity for ammonia (calculated using the sprayed-bundle model presented in [23,25]) were taken from [23]. The velocities of propane and freon-114 were then deduced from the property comparison. As shown in Fig. 14, freon-114 is not a suitable fluid for a sprayed bundle unless the bundle diameter is small or vapor lanes are incorporated into the bundle layout. More information on shell-side velocities and liquid entrainment in both horizontal and vertical film heat exchangers is given in [24].

In flooded-bundle evaporators, the hydrostatic head increases the saturation temperature of the working fluid. This is an especially serious problem in OTEC flooded bundles, since the overall value of $\Delta T$ is small. A possible solution is the use of the High-Flux surface for which the required wall superheat is very small [11].

By anaiyzing the change in the saturation temperature with the hydrostatic head in the bundle, maximum bundle depths can be determined for the three fluids (see Fig. 15). For the High-Flux surface Czikk et al. [11] found that the maximum depth is $15 \mathrm{ft}$ for ammonia. By a similar argument the maximum depth is found to be about $15 \mathrm{ft}$ for propane and $2 \mathrm{ft}$ for freon-114. The use of multiple flooded bundles has been suggested [11,15] to avoid the hydrostatic-head effect. However, unless a novel design is developed, the cost of multiple flooded bundles will be very high for freon-114. 


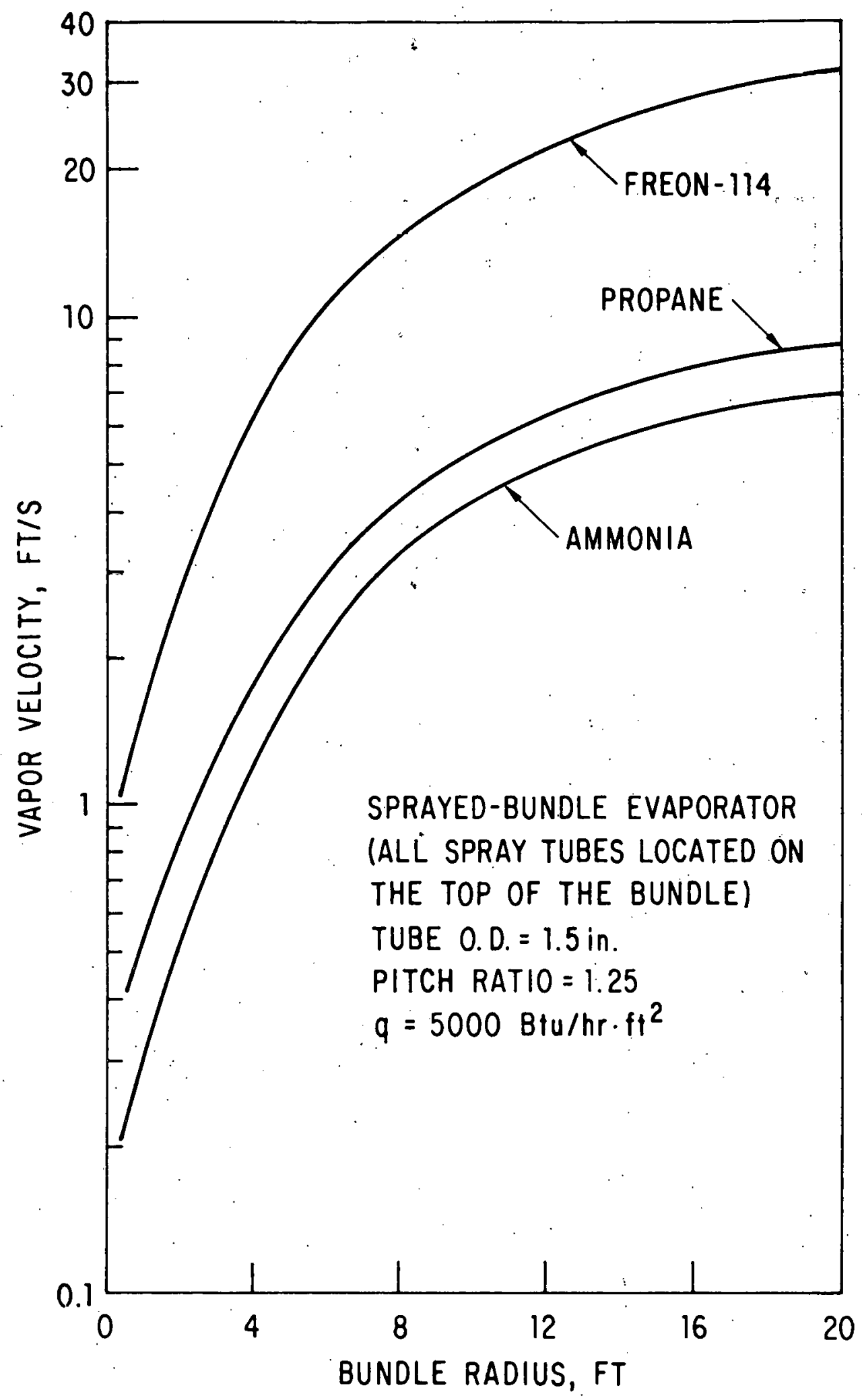

Fig. 14. Vapor Velocity versus Sprayed-Bundle Radius 


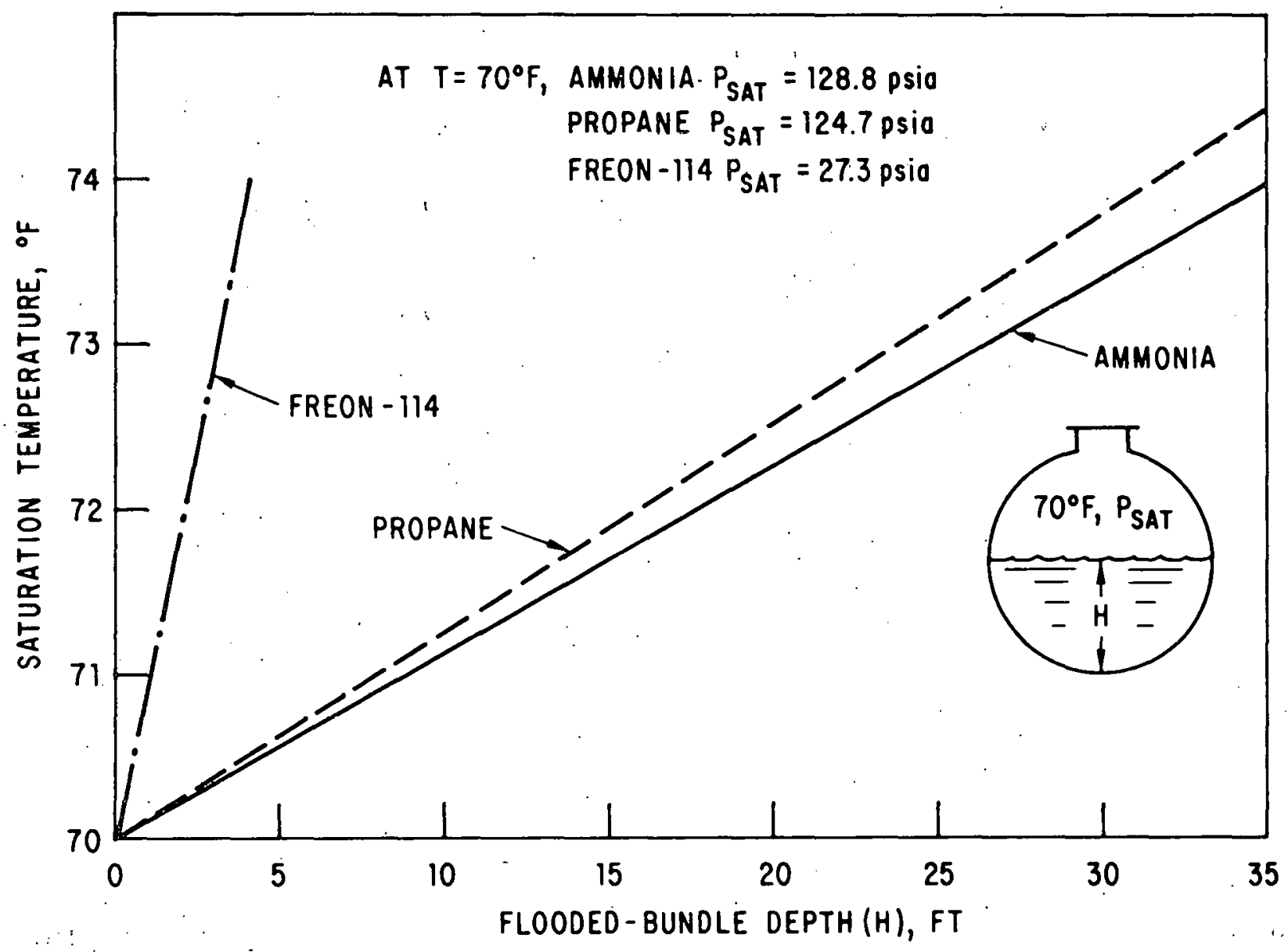

Fig. 15. Change of Saturation Temperature with Flooded-Bundle Depth (Extrapolation) 


\section{CONCLUDING REMARKS}

This report has shown that ammonia is superfor to propane and freon114 for the Case 1 and Case 5 systems (thin-film heat exchangers) because of its very high thermal conductivity (Table 2). For propane and freon-114 the heat transfer areas of the thin-film heat" exchangers appear unacceptably large if a surface enhancement is not applied. However, if the High-Flux surface is used (Case 3 and Case 4), thermal conductivity is not as important (see Sec. 3), and almost all resistance to heat transfer is on the seawater side for all three fluids. The size and cost of the turbine must be determined in order to justify the superiority of ammonia over propane and freon114 in this case. Ammonia's toxic nature and the problems it creates with turbine seals and materials are also important considerations. If ammonia is not used, other heat exchanger tube materials and their cost should be considered in conjunction with the size and cost of the turbine. For example, 90/10 cupronickel exhibits excellent resistance to corrosion and biofouling, and is currently considered the standard in the seawater condenser industry [11]. (The cuprous alloys cannot be used with ammonia because of stress corrosion cracking problems.)

From the above and from the results given in Sec. 5, it is evident that the choice of a working fluid for OTEC depends strongly on the type of heat exchanger involved. When the type of exchanger is specified, its heat transfer processes can be analyzed. The effect of a particular working fluid's properties on the size of the exchanger can then be determined and design problems can be identified.

In addition to the three fluids discussed in this report, freon-22, freon-12, butane, and sulfur dioxide are also considered to be candidates for the OTEC cycle $[26,27]$. As shown in Fig. 2, these fluids have suitable vapor pressures in the temperature range of interest. From the results of this report, various conclusions can be drawn about the applicability of these fluids to OTEC. For example, in the case of a horizontal thin-film evaporator, size will be proportional to the liquid-phase thermal conductivity of the fluid in question. The vapor velocity on the shell side of a sprayed-bundle evaporator will be proportional to the values of $i_{f g} / v_{g}$ if the surface heat flux is approximately constant. Other conclusions such as 
these can be drawn based on this study.

For all three fluids and seven exchanger combinations considered, the efficiency of the 1 MWe system was about 3\%. For the same conditions* the efficiency of the 25 MWe system was lower (about $2.8 \%$ ), partly due to the greater tube length. Similar conclusions about efficiency can be drawn from $[26,27]$ :

The study of working fluids should be continued since OTEC is a longrange energy alternative. The analysis and comparison of working fluids presented here was limited to those fluids whose properties are known. At present, more work should be done on mixtures and pure fluids whose basic physical thermodynamic properties are unknown. From the literature survey undertaken by the authors, it is concluded that the method of thermodynamic functions is appropriate in evaluating fluids for which data are unavailable. Thermodynamic functions are derived from generalized equations of state and can be used to predict enthalpy, entropy, internal energy, and specific heat as functions of temperature and density [28]. Furthermore, these thermodynamic function relations can be conveniently used with parametric and optimization techniques to determine the fluid properties and cycle conditions that maximize system efficiency. Once the fluid properties are identified, a specific heat exchanger design can be selected.

The minimum information required for the generalized function approach includes the fluid's chemical structure and either its critical temperature or its boiling point. The transport properties of fluids are given by various relations summarized in [2].

* Generally, the turbine and pump efficiencies will be higher for the 25 MWe system than for the 1 MWe system; consequently, the efficiency of the 25 MWe system will be greater. 


\section{REFERENCES}

1. ASHRAE Handbook of Fundamentals, Chapters 14 and 31 , American Society of Heating, Refrigerating and Air-Conditioning Engineers, New York, N.Y. (1976).

2. Perry, R.H., and C.H. Chilton, Chemical Engineer's Handbook, Chapter 3, McGraw-Hill, New York, N.Y. (1973).

3. Bartz, J.A., Heat Rejection by Dry Cooling in Steam-Electric Power Stations, report prepared for EPRI, Union Carbide Corp., Linde Division, Tonawanda, N.Y. (April 1976).

4. Baumeister, T., ed., Mark's Standard Handbook for Mechanical Engineers, Chapter 19, McGraw-Hill, New York, N.Y. (1978).

5. Rohsenow, W.J., and H.Y. Choi, Heat, Mass and Momentum Transfer, PrenticeHall, Englewood Cliffs, N.J. (1961).

6. Lorenz, J.J., and D. Yung, A Note on Combined Boiling and Evaporation of Liquid Films on Horizontal Tubes, J. Heat Transfer, 101(1):178-180.

(Feb. 1979).

7. Chun, K.R., and R.A. Seban, Heat Transfer to Evaporating Liquid Films, J. Heat Transfer, Transactions of the ASME, Series C, 93:391-395 (1971).

8. Colburn, A.P., Note on the Calculation of Condensation when a Portion of the Condensate Layer is in Turbulent Motion. Transactions of the American Institute of Chemical Engineers, Vol. 30, pp. 187-193 (1933).

9. Palen, J.W., et al., Characteristics of Boiling Outside Large-Scale Horizontal. Multitube Bundles, AIChE Symposium Series, Vol. 68, No. 118, pp. 50-61 (1973).

10. Mostinski, I.L., Application of the Law of Corresponding States to the Calculation of Heat Transfer and Critical Heat Fluxes during the Boiling of a Liquid (translation), Teploenergetika, 10(4):66-71 (1963); English abstract in British Chemical Engineering, 8(8):580 (1963).

11. Czikk, A.M., et al., Ocean Thermal Power Plant Heat Exchangers, final report to ERDA, Union Carbide Corp., Linde Division, Tonawanda, N.Y. (1976).

12. Lorenz, J.J., Argonne National Laboratory, private communication (July 1978).

13. Fricke, H.D., Union Carbide Corp., Linde Division, private communication (Aug. 1978).

14. Thomas, D.G., Enhancement of Film Condensation Heat Transfer Rates on Vertical Tubes by Vertical Wires, Industrial and Engineering Chemistry Fundamentals, 6(1):97-102 (1967). 
15. Czikk, A.M., et al., Enhanced Performance Heat Exchangers, Proc. Fourth Annual Conf. on Ocean Thermal Energy Conversion, New Orleans, La., pp. VI-71-92 (1977).

16. Nakayama, W., et al., High Performance Heat Transfer Surface -- Thermoexcel, Hitachi Review, 24(8):329-334 (1975).

17. Hitachi Thermoexcel, catalogue number EA-501, Hitachi Cable, Ltd., Tokyo (1978).

18. Bergles, A.E., and M.K. Jensen, Enhanced Single-Phase Heat Transfer for OTEC System, Proc. Fourth Annual Conf. on Ocean Thermal Energy Conversion, New Orleans, La., pp. VI-41-54 (1977).

19. Ioup, G.E., ed., Proc. Fourth Annual Conf. on Ocean Thermal Energy Conversion, Section IV, Heat Exchangers, New Orleans, La. (1977).

20. Grant, I., Thermodynamics and Heat Power, Reston Publishing Co., Reston, Va. (1974).

21. Reynolds, W.C., and H.C. Perkins, Engineering Thermodynamics, McGrawHi11, New.York, N.Y. (1977).

22. Ganic, E.N., and L. Moeller, On the Optimization of an Ocean Thermal Energy Conversion System, Proc. Fifth Ocean Thermal Energy Conversion Conf., Miami Beach, Fla., pp. V-147-163 (1978).

23. Czikk, A.M., et al., Fluid Dynamic and Heat Transfer Studies of OTEC Heat Exchangers, Proc. Fifth Ocean Thermal Energy Conversion Conf., Miami Beach, Fla., pp. VI-181-236 (1978).

24. Yung, D., et a1., Vapor/Liquid Interaction and Entrainment in ShelZ-andTube Evaporators, Argonne National Laboratory Report ANL-OTEC-78-2 (June 1978) and ASME Paper No. 78-WA/HT-35 (1978).

25. Ganic, E.N., and A.M. Czikk, An Analytical Model of Sprayed Bundle Evaporator, Linde Report, Union Carbide Corp., Tonawanda, N.Y. (Aug. 1977).

26. McGowan, J.G., et a1., Ocean Thermal Difference Power-Plant Design, J. Engineering for Industry, 96(4):1119-1128 (Nov. 1974).

27. Ne1son, M.I., Ocean Thermal Energy Conversion Plant Working Fluid Study, paper presented at the Fifth Ocean Thermal Energy Conversion Conf.; Miami Beach, Fla. (1978).

28. Henry, C.D., A Generalized Approach to Thermodynamic Cycle Analysis, $\mathrm{Ph} . \mathrm{D}$. thesis, Department of Nuclear Engineering, University of Arizona (1977).

29. Owens, W.L., Correlation of Thin Eilm Evaporation Heat Transfer Coefficients for Horizontal Tubes, Proc. Fifth Ocean Thermal Energy Conversion Conf., Miami Beach, Fla., pp.VI-71-89 (1978). 
30. Abelson, H.I., OTEC Power System Performance Model, Report No. MTR-7924, The Mitre Corp., McLean, Va. (Aug. 1978).

31. Lewis, L.G., and N.F. Sather, OTEC Performance Tests of the Union Carbide Flooded-Bundle Evaporator, Argonne National Laboratory Report ANL/OTEC-PS-1 (Dec. 1978). 
The authors wish to acknowledge the useful comments and suggestions made by Drs. J. J. Lorenz, N. F. Sather, and D. Yung during the course of this work. The assistance of Professor A. Lavi of Carnegie-Mellon University and Mr. H. I. Abelson of Mitre Corporation in reviewing the preliminary version of the report is also much appreciated. We also thank Christine Lemberg for editorial assistance, and Bobbi Walker for secretarial services. 
APPENDIX

Results for the 25 MWe OTEC System 


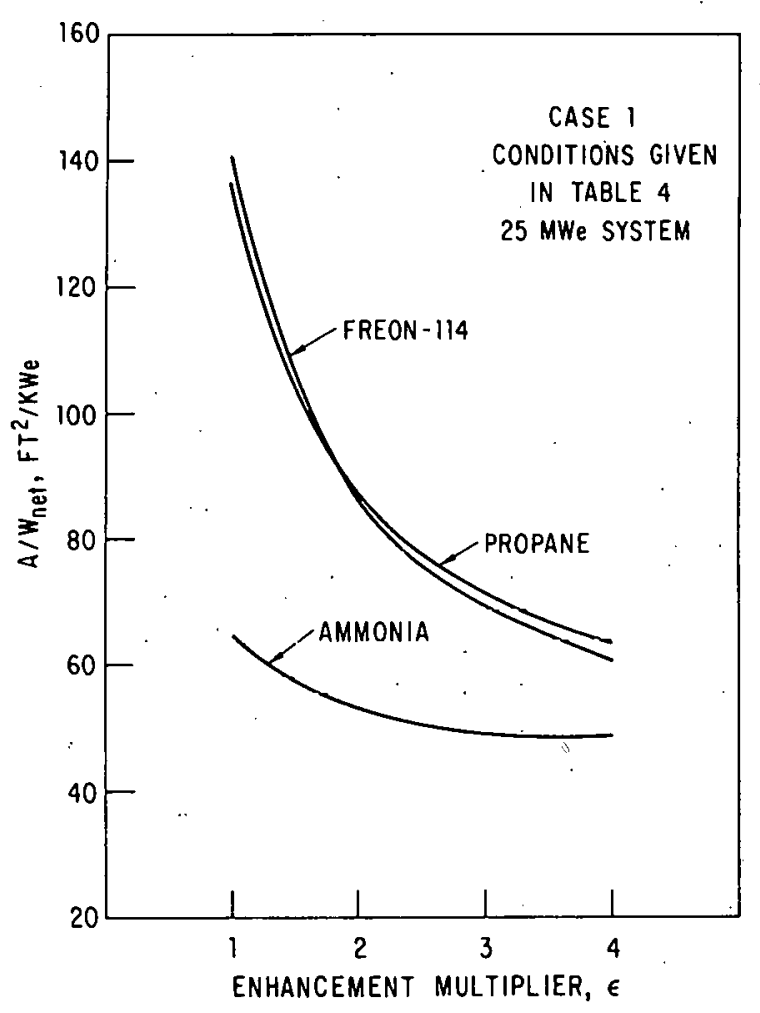

Fig. A.1. Case 1: Variation of $\mathrm{A} / \mathrm{W}_{\text {net }}$ as a Function of Shell-Side Enhancement

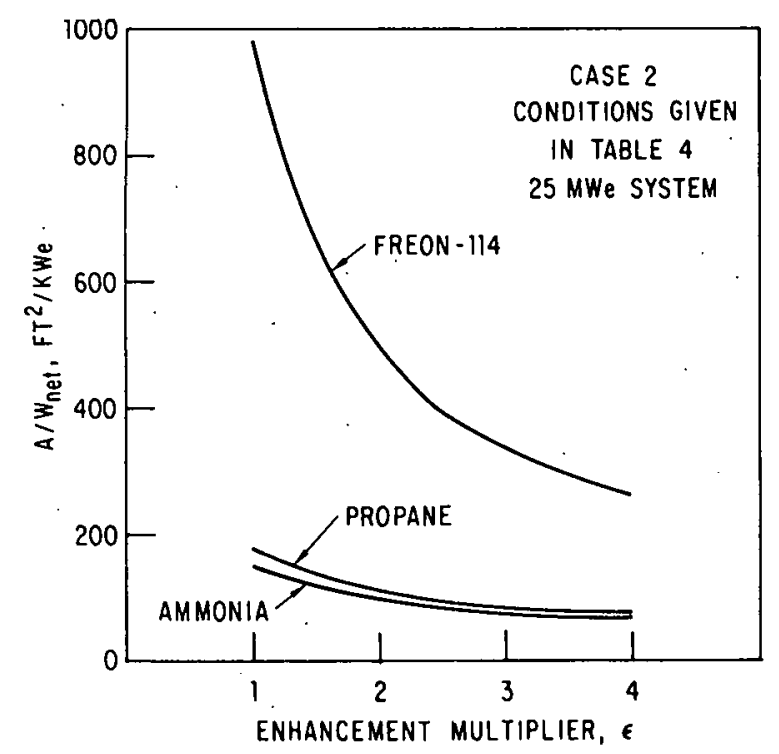

Fig. A.3. Case 2: Variation of $\mathrm{A} / \mathrm{W}_{\text {net }}$ as a Function of Shell-Side Enhancement

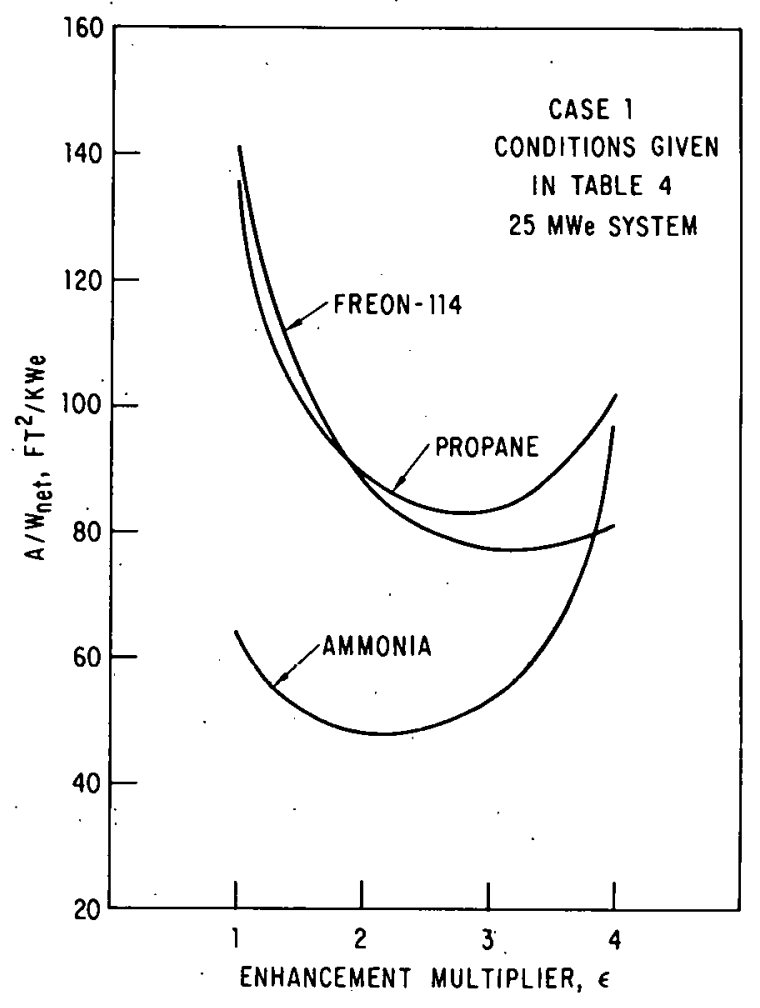

Fig. A.2. Case 1: Variation of $A / W_{\text {net }}$ as a Function of Shell-Side and Tube-Side Enhancement

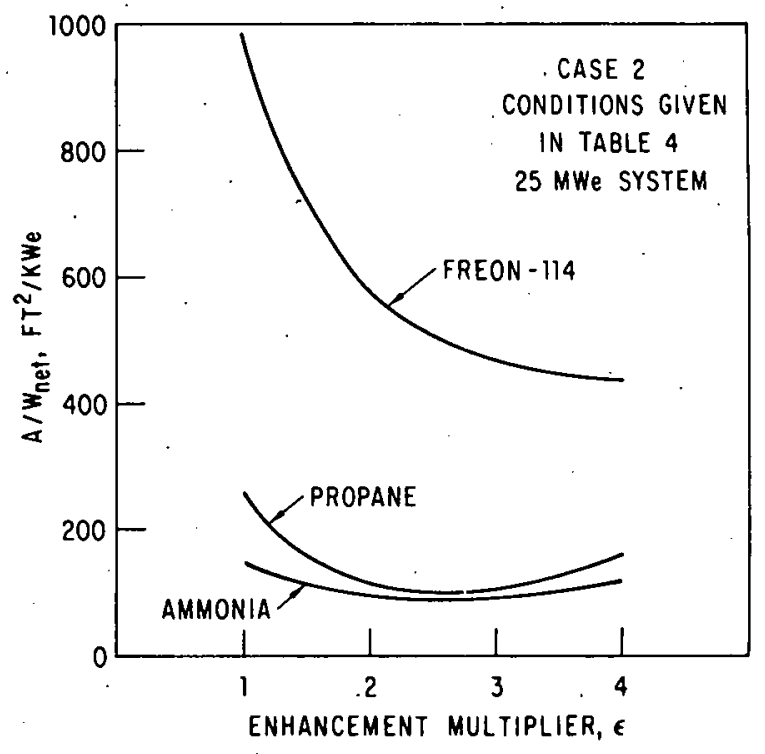

Fig. A.4. Case 2: Variation of $A / W_{\text {net }}$ as a Function of Shell-Side and Tube-Side Enhancement 


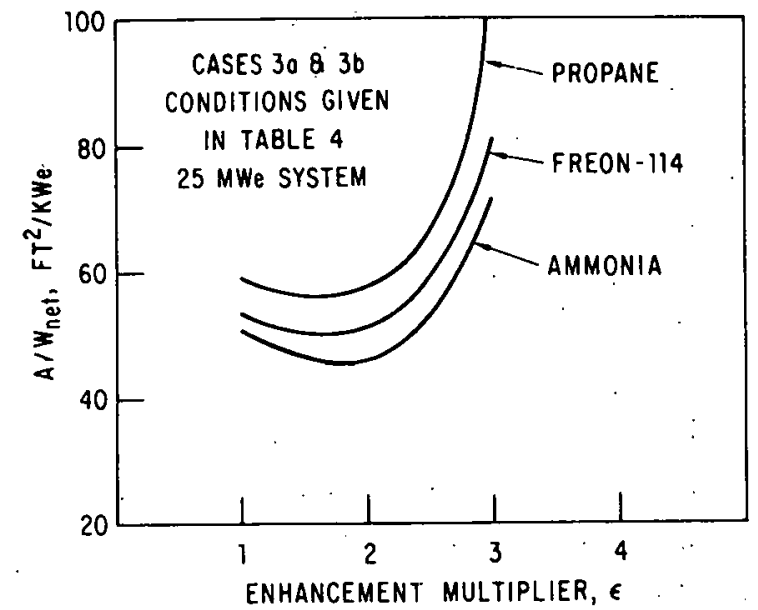

Fig. A.5. Cases $3 a$ and $3 b$ : Variation of $A / W_{\text {net }}$ as a Function of Tube-Side Enhancement

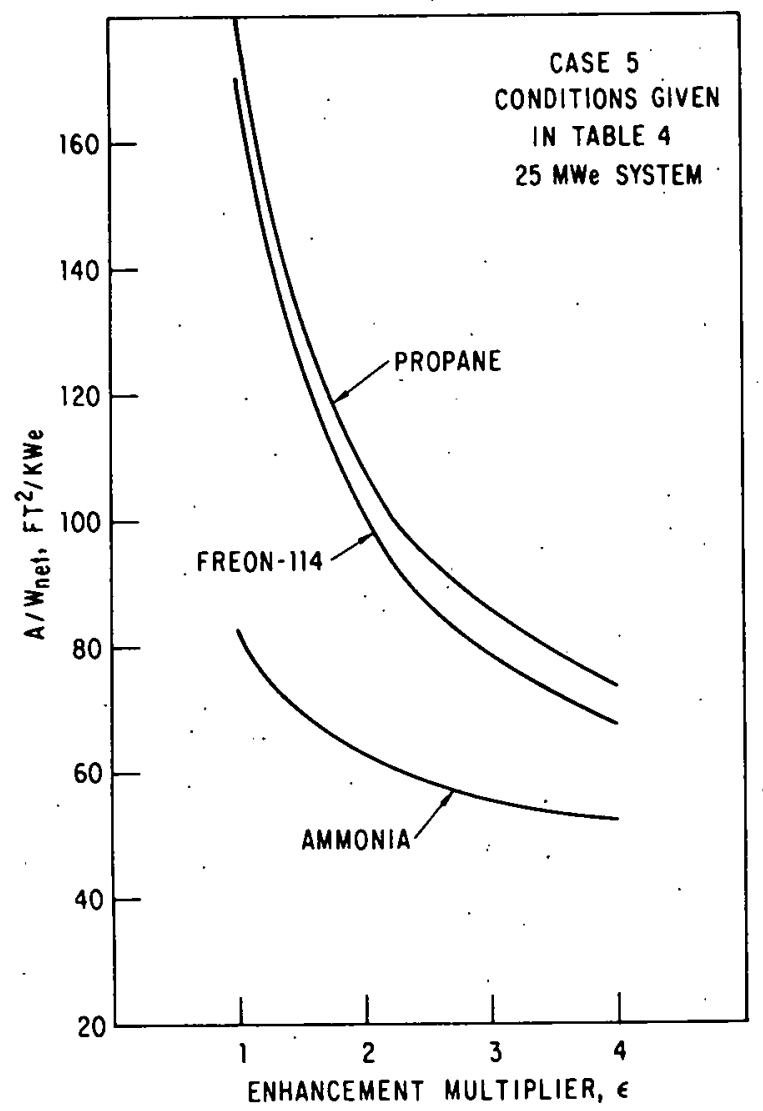

Fig. A.7. Case 5: Variation of $\mathrm{A} / \mathrm{W}_{\text {net }}$ as a Function of Shell-Side Enhancement

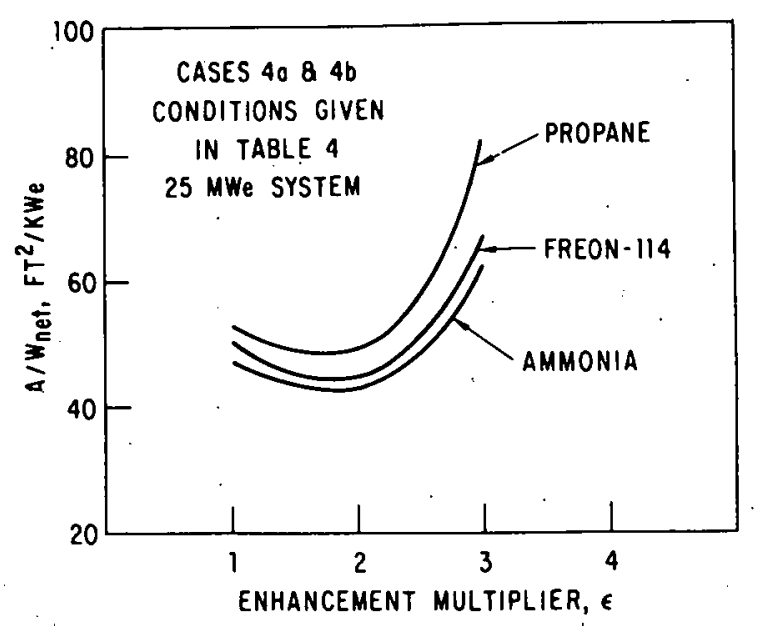

Fì. A.6. Cases $4 a$ and 4b: Variation of $A / W_{\text {net }}$ as a Function of Tube-Side Enhancement

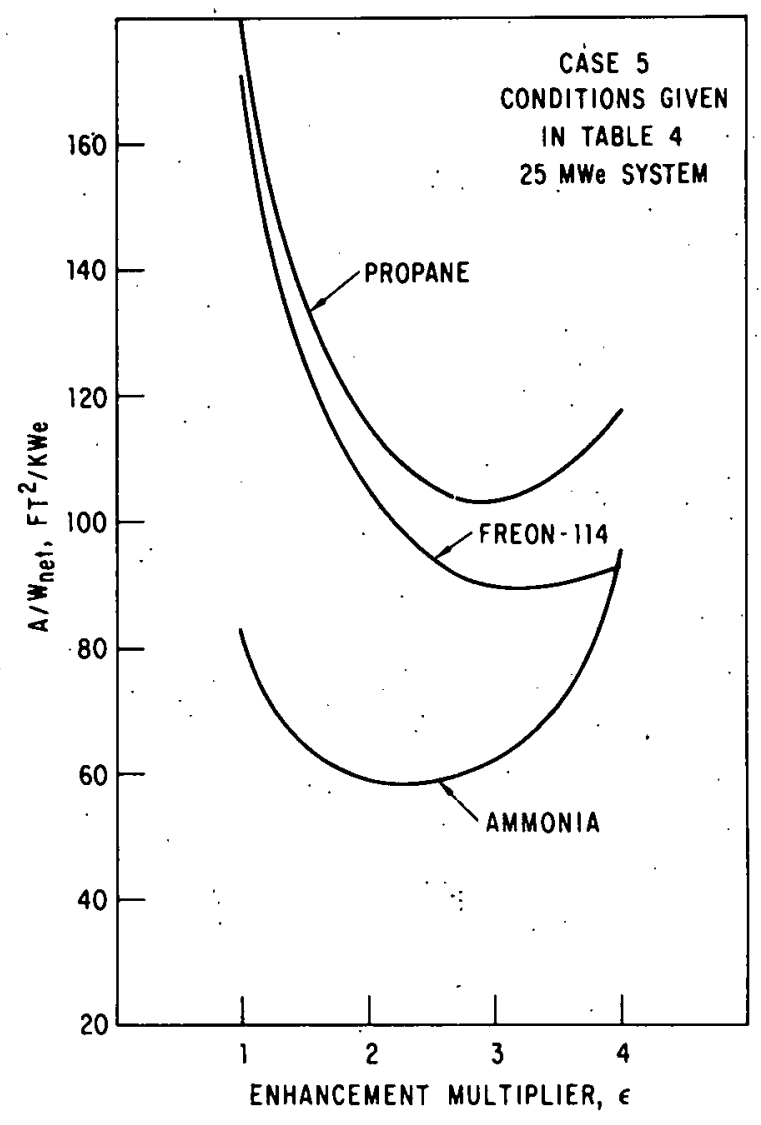

Fig. A.8. Case 5: Variation of $A / W_{\text {net }}$ as a Function of She11-Side and Tube-Side Enhancement 